\title{
THE MODENA RELIEF: A MYSTERY OF WHAT?
}

\begin{abstract}
Summary: The subject of my paper concerns the iconography of the mysterious relief at Modena (Galleria Museo e Medagliere Estense, inv. 2676) showing a young god in a cosmic egg. The paper is to review the state of research in modern scholarship since 1863, to discuss various attempts at its interpretation, and to propose my own working hypothesis, which links the Modena relief to the Orphic Rhapsodies and the Middle-Platonic passage transmitted by Porphyry of Tyre in his The Cave of the Nymphs 21-29.
\end{abstract}

Key words: Modena relief, iconography, interpretations, Mithras, Phanes, Orphic cosmogonies

\section{THE PHYSICAL DESCRIPTION}

The Roman bas-relief dating from 125-150 AD has been kept in the Galleria Estense at Modena since 1752. The dimensions of the relief, when I measured it myself, ${ }^{1}$ were the following: $71 \mathrm{~cm}$ in height, $48 \mathrm{~cm}$ in width, and 5-6 cm in thickness. It is a rectangular piece of stonework, its thickness is uneven, the back is rough, and the right side has a fracture (fig. 1). It follows that the piece must have been extracted from something bigger to which it originally belonged. On the top, some traces of corrosion can be seen due to a metal hook which fixed it (fig. 2). In any case, the state of preservation of its carved surface is still excellent.

In the white veined marble, a beardless young man of amazing beauty is shown (fig. 3). He has a serene face and short wavy hair. His well-muscled body is equipped with a pair of wings and cloven hoofs instead of human feet. A lunar crescent protrudes from his athletic shoulders, and three animal foreheads (of a ram, a lion, and a he-goat) grow out of his naked chest (fig. 4). In addition, a huge snake coils around

\footnotetext{
${ }^{1}$ Thanks to the kindness of dr. Nicoletta Giordani, the director of Museo Lapidario Estense, I have been allowed to measure the Modena relief and take some photos of it. It was on May 28th 2014.
} 


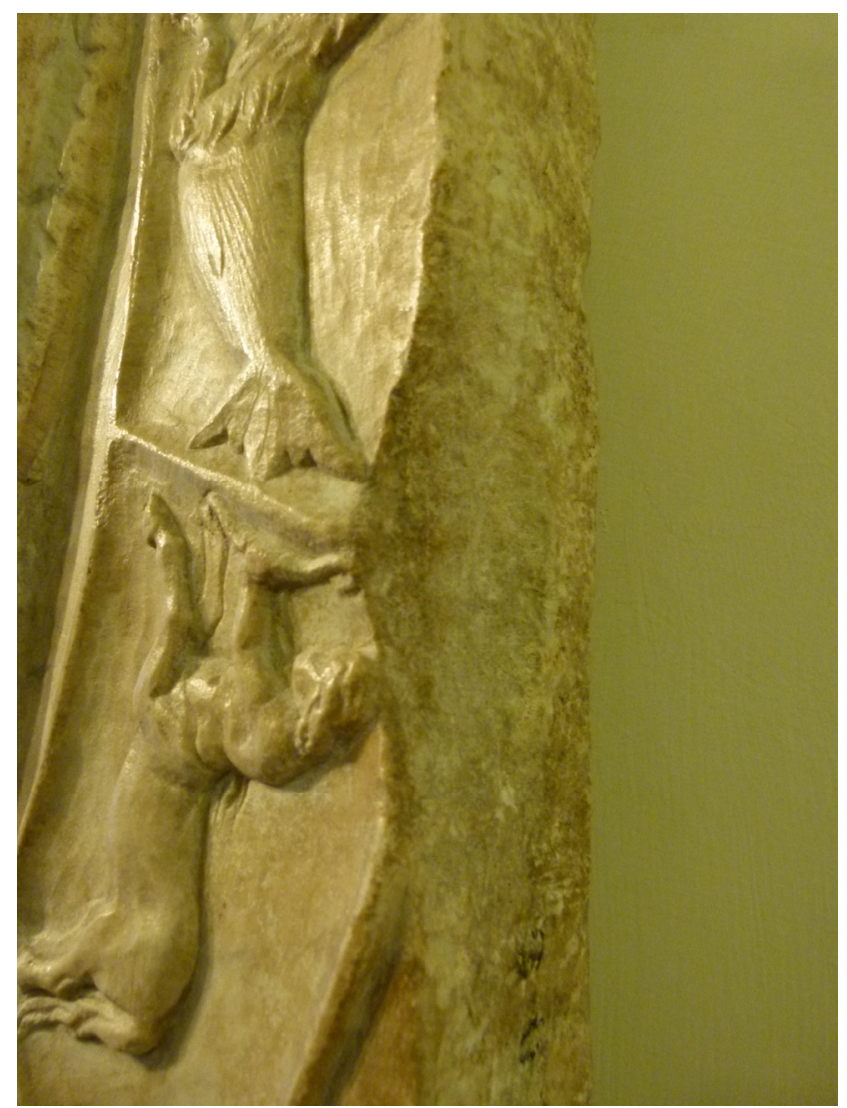

Fig. 1.

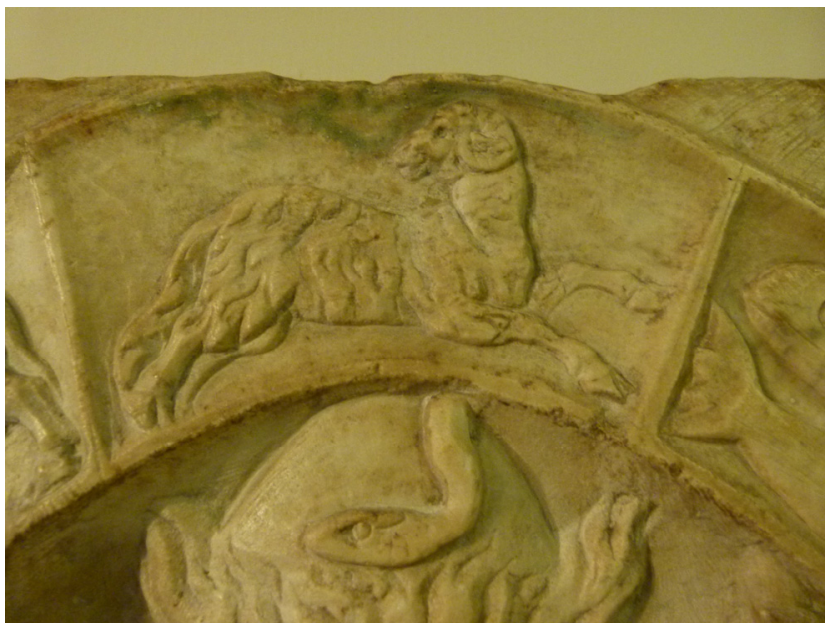

Fig. 2. 


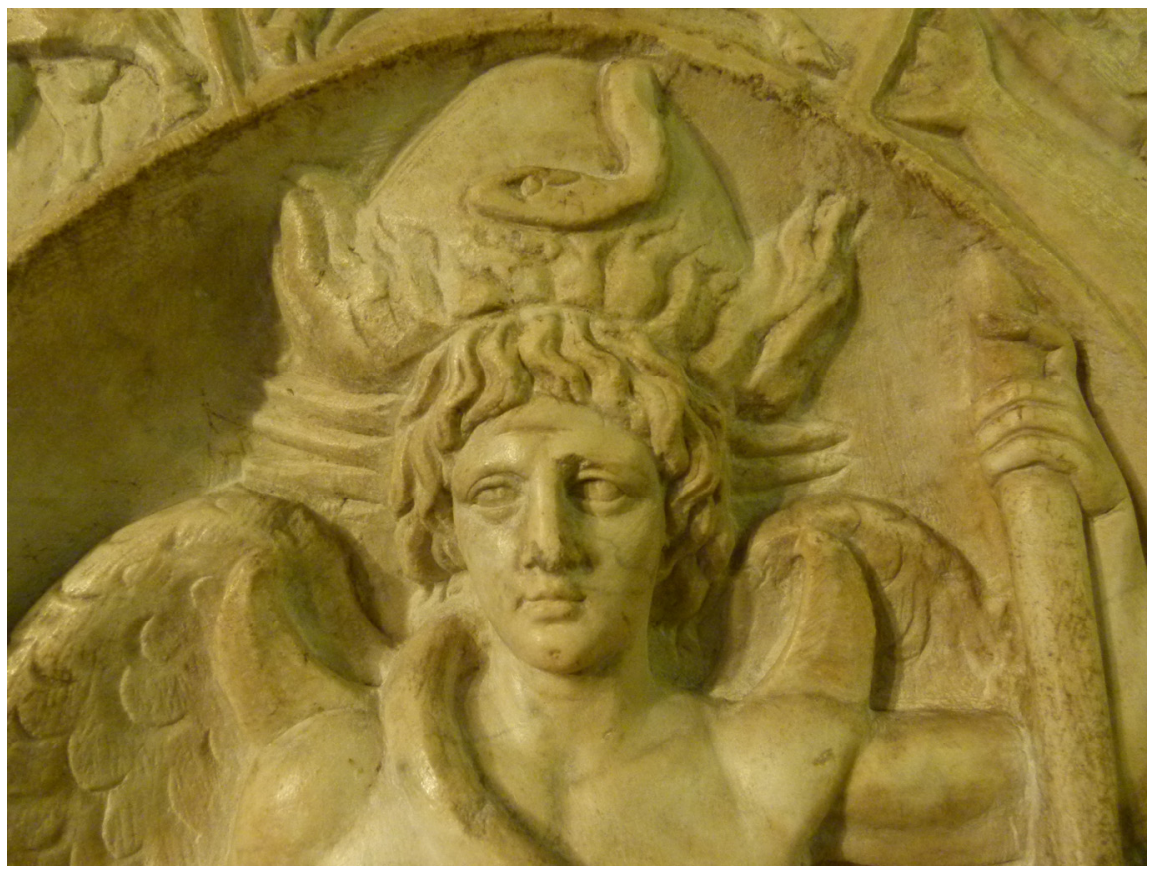

Fig. 3.

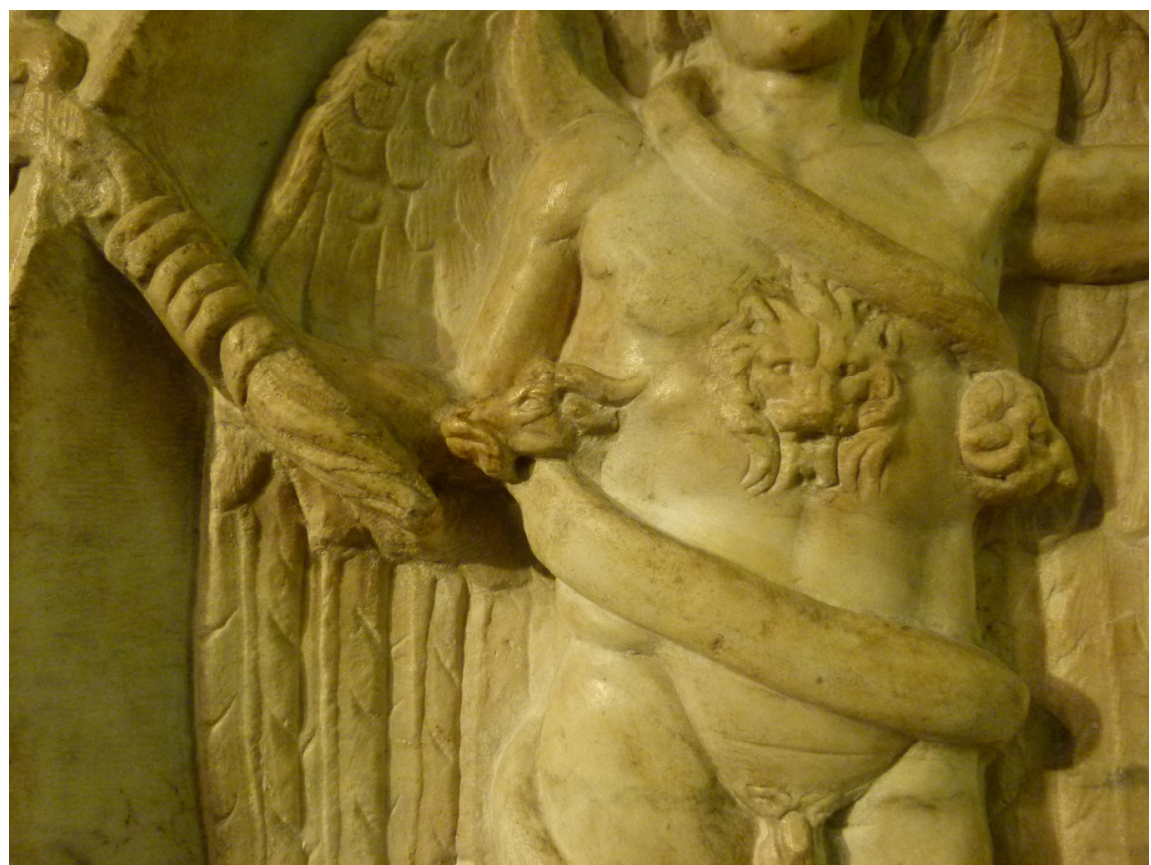

Fig. 4. 


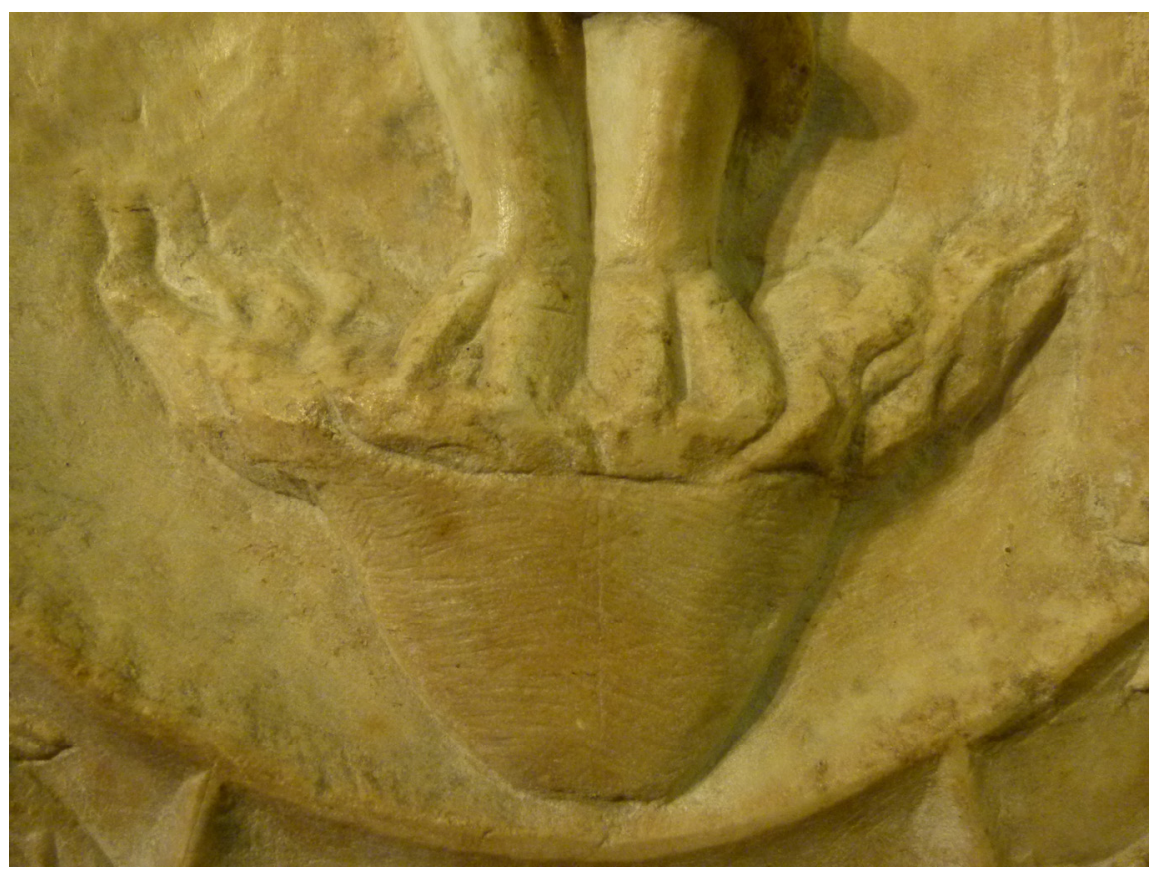

Fig. 5.

his body in four spirals to form a uraeus-like crown upon his head. The youth is represented as just having come out of a broken egg, with the round half of the egg above his head and the conic top beneath his feet (fig. 5), so he seems to integrate the two halves. Flames pour from the upper and lower eggshells to illuminate his beautiful face and his hoofs.

The one-in-egg is standing in an oval niche, resembling the interior of an egg that is enclosed by a Zodiac mandorla. He is standing exactly on the line of equinoxes, with Aries above his head and Libra under his feet, Cancer on his right and Capricorn on his left. With a torch in his right hand he illuminates the sign of Gemini (fig. 6) and points to Pisces with a long scepter he holds in his left (fig. 7). In the corners, outside the Zodiac belt, there are four male heads, portrayed in their profiles, that have wings in their hair. Two of them (those on the left) are represented as old bearded men, while the remaining two are portrayed as younger beardless men.

The relief bears two Latin graffiti. The upper one, situated below the right wing of the god, had been written and then erased, so it is indecipherable: IIIII ROSY / $\mathrm{N}[\ldots] \mathrm{II}$ I IIIX ${ }^{2}$ (fig. 8). The second graffito is placed just upon the bottom, next to the two male heads. It reads FELIX PATER. The letters are legible but clumsy, written with an unskilled hand, in contrast to the fine stonework of the relief (fig. 9). Above

\footnotetext{
${ }^{2}$ MastrocinQue, A.: Studi sul mitraismo: il mitraismo e la magia. Roma 1998, 102 n. 351.
} 


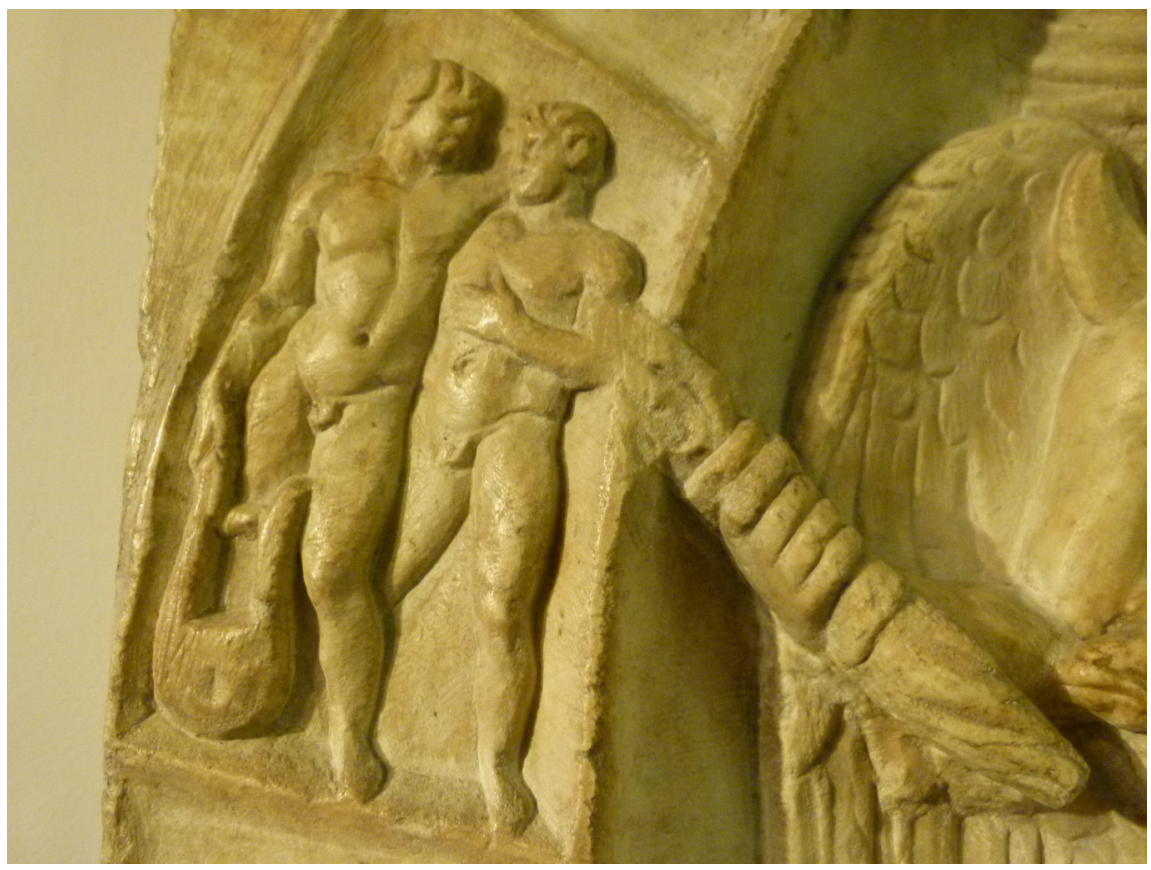

Fig. 6.

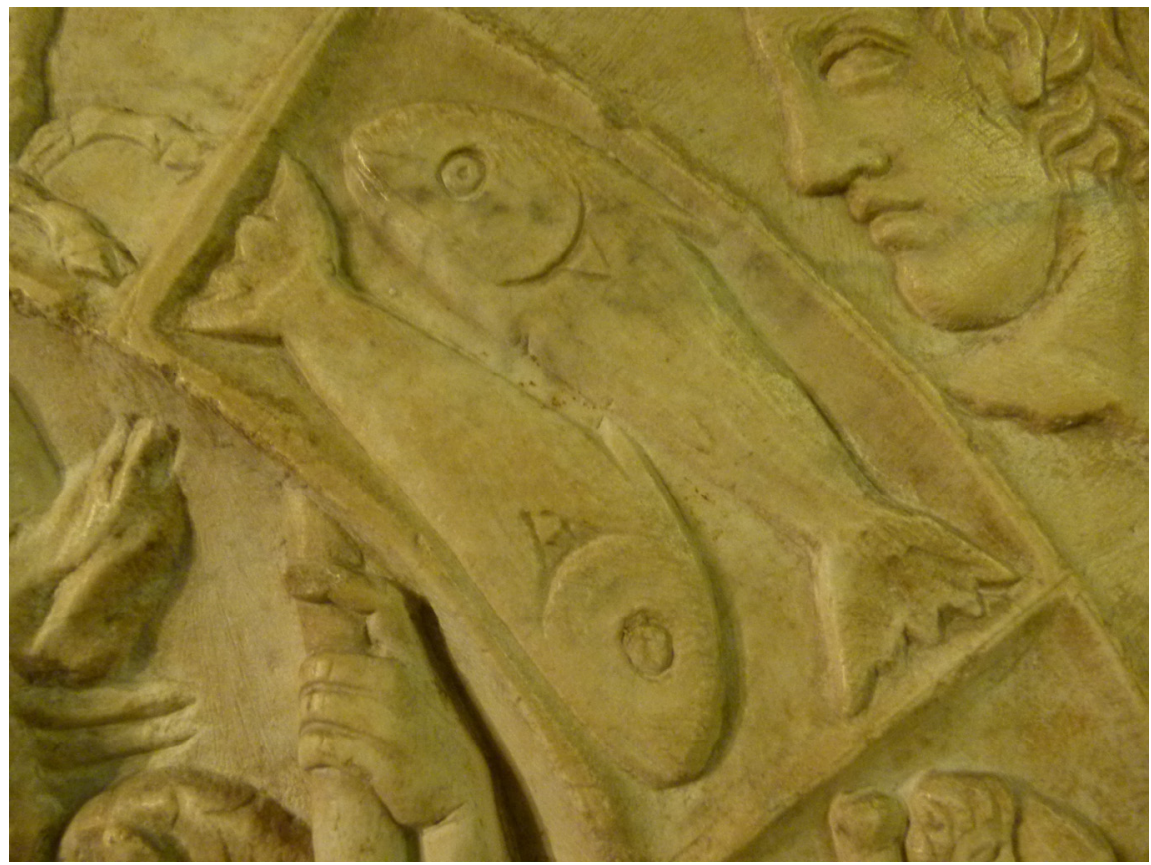

Fig. 7. 


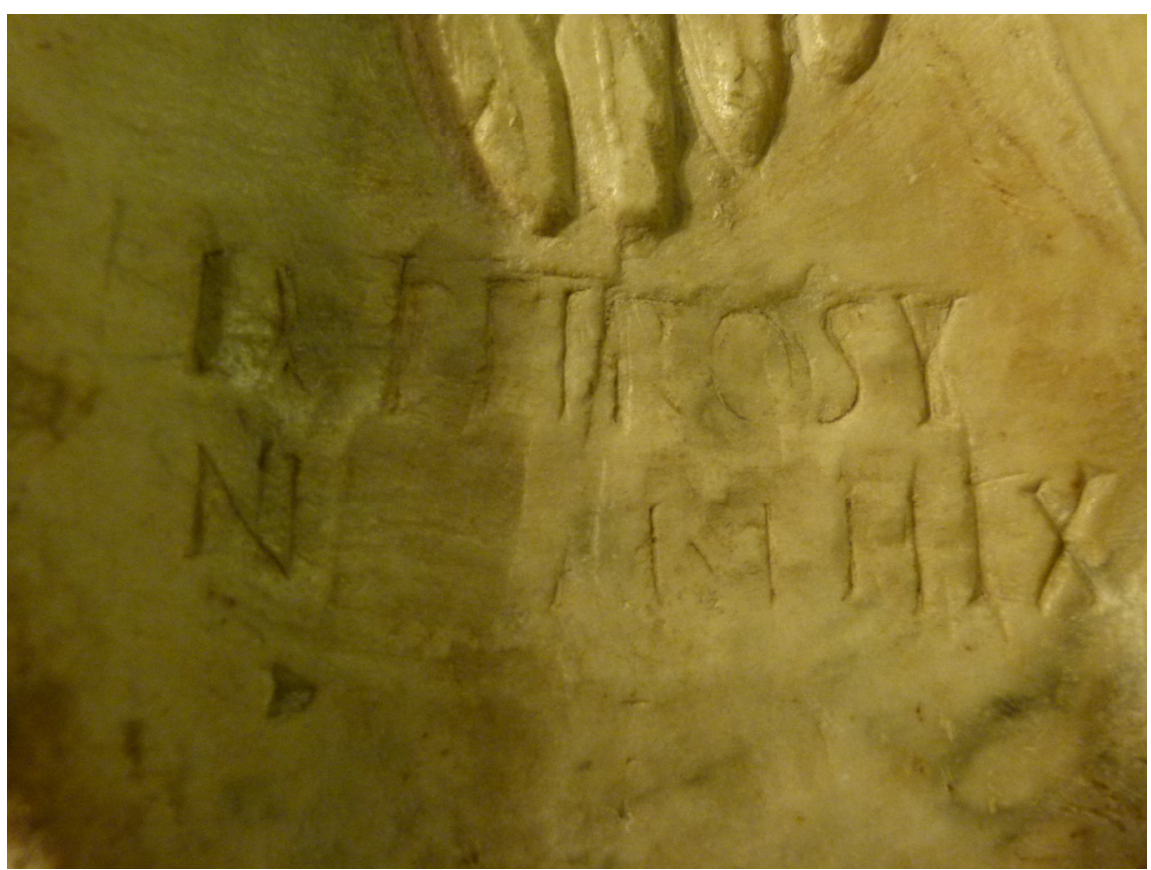

Fig. 8.

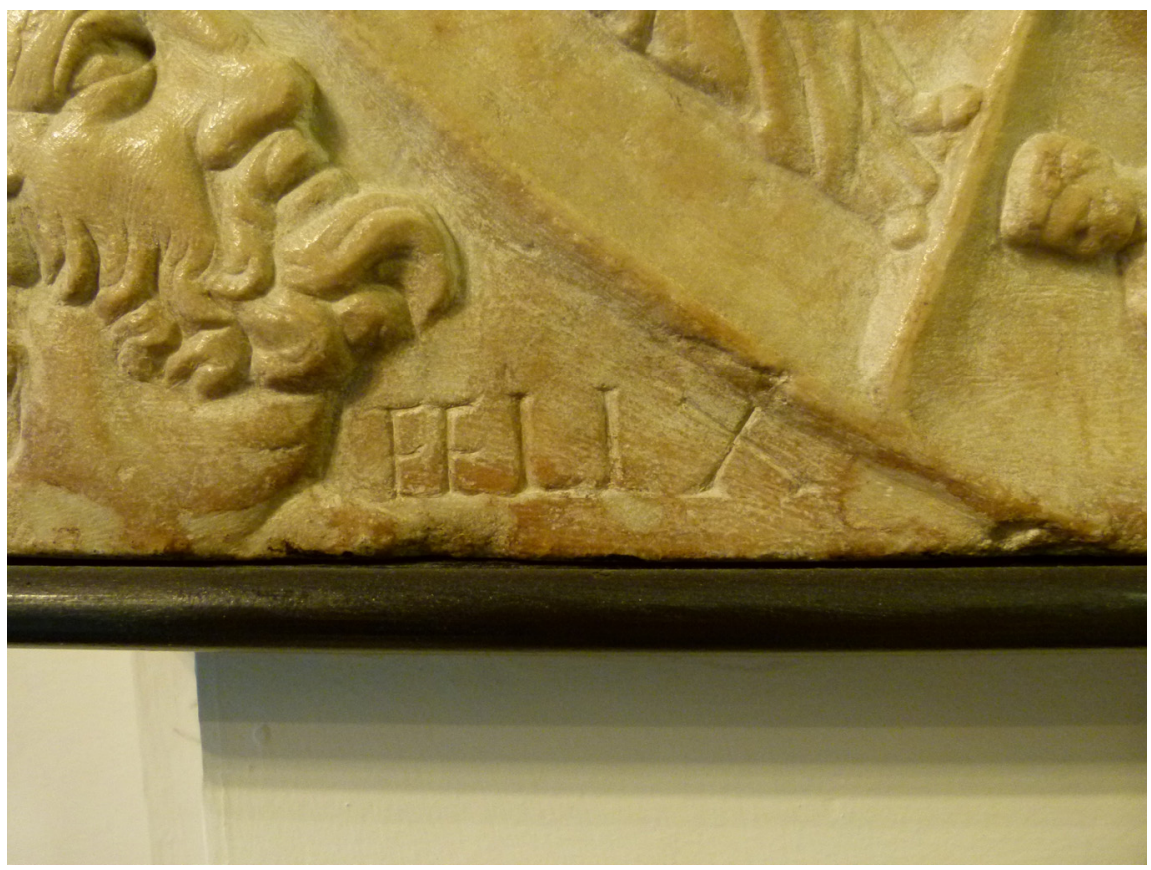

Fig. 9. 
the Felix Pater inscription, the same hand engraved the double PP, which seems to be an abbreviation. These two graffiti are evidently ancient inscriptions that have been preserved from the Roman period.

\section{STATUS QUAESTIONIS SINCE 1863}

The secondary literature devoted to the Modena relief is enormous. Most scholars used to focus on the question of what deity is represented within the egg. The very first of them, Monsignor Celestino Cavedoni (1863) deciphered the illegible inscription as IUPPITER OSYRI. . FELIX, and consistently interpreted the radiant youth as the syncretistic Osiris-Mithras, like the one in Statius' Thebaid 1. 717-720 (Osirim... Mithram), and the egg from which the god has sprung as the Orphic egg, like that referred to by Plutarch in his Table Talks 635E. Cavedoni was the first to publish the Modena relief and to recognize the Orphic influence on it. ${ }^{3}$

Franz Cumont (1902) republished the Modena relief and deciphered the obliterated inscription differently: EUPHROSYNE ET FELIX. He interpreted the god-inthe-egg as the Mithraic Chronos - a personification of the endless Time, or Aion (he meant here the lion-headed monster, the so-called leontocephaline, e.g. CIMRM 312, CIMRM 545), ${ }^{4}$ and he explained the lunar crescent as an attribute of Men, the moon god, and the egg-halves as the celestial hemispheres, arguing that they have nothing to do with the Orphic egg. Furthermore, he interpreted the three animal masks on the god's chest as symbols of the Tropics and of the seasons: the ram standing for Aries and spring, the lion for Leo and summer, and the he-goat for Capricorn and fall. ${ }^{5}$ Cumont, however, did not include the Modena relief into his own corpus of Mithraic monuments edited six years earlier (1896). ${ }^{6}$

Robert Eisler (1910) speculated as follows: the monument had been dedicated by a couple, a woman, Euphrosyne, and her husband, Felix, to be placed in their Orphic sanctuary. However, following their divorce or the death of his wife, Felix became a Mithraist, so he erased the name of Euphrosyne, re-dedicated the relief, and added his own name and grade: FELIX PATER, to be placed in his private chapel, or mithreum. ${ }^{7}$ Eisler based his speculation on the reading proposed by Cumont: EUPHROSYNE ET FELIX and the well-known "fact" that women were totally

${ }^{3}$ Cavedoni, C.: Dichiarazione di un bassorilievo Mitriaco della R. Galleria Palatina di Modena. Atti e memorie delle Rr. Deputazioni di Storia Patria per le Provinzie Modenesi e Parmensi 1 (1863) 1-4 and fig. 1.

${ }^{4}$ CIMRM = VERMASEREN, M. (ed.): Corpus inscriptionum et monumentorum religionis Mithriacae. 2 vols. The Hague 1956-1960.

${ }^{5}$ CUMONT, F.: Notice sur deux bas-reliefs mithriaques. RA 40 (1902) 1-10 and pl. 1. The same is stated in Cumont, F.: The Mysteries of Mithra. Trans. T. J. McCormack. Chicago 1903, 223 and fig. 49 [French original 1902].

${ }^{6} M M M=$ CuMONT, F. (ed.): Textes et monuments figurés relatifs aux mystères de Mithra. Vol. 2. Bruxelles 1896.

${ }^{7}$ EISLER, R.: Weltenmantel und Himmelszelt: Religionsgeschichtliche Untersuchungen zur Urgeschichte des Antiken Weltbildes. Bd. 2. München 1910, 399-401 and fig. 47. 
excluded from the mysteries of Mithras. ${ }^{8}$ In any case, Eisler was the first to identify the god-in-the-egg with the Orphic Phanes. Sir Arthur Cook in his Zeus (1925) accepted Eisler's hypothesis. ${ }^{9}$

Franz Cumont (1934) changed his previous view (1902) after discovering three dedicatory inscriptions on Aventine Hill, Rome, in $1931 .{ }^{10}$ One of them, dating from

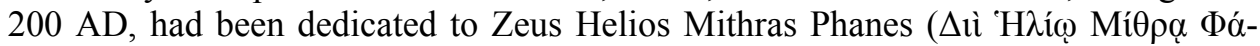
$v \eta \tau \imath$ ) by a certain Venustus, the Mithraistic high priest, and his servants (CIMRM 475). ${ }^{11}$ The new discovery, which is evidence for the Mithras-Phanes syncretism in the 3rd-century Rome, ${ }^{12}$ allowed Cumont to identify the Modena god with the Orphic Phanes, who hatched from an egg laid by Heracles and, at the same time, with Mithras Petrogenitus - born from the cosmic rock, petra genetrix. To reinforce his standpoint, Cumont compared the Modena relief to another Mithraistic monument, found in Housesteads, Northumberland, in 1822, which depicts Mithras as born from a broken egg instead of a rock $\left(C I M R M\right.$ 860). ${ }^{13}$ It can be taken for granted that the Housesteads relief represents Mithras because the inscription found nearby reads: Deo Soli Invicto Mytrae Saeculari (CIMRM 864). It should be noted, however, that the drawing made before the reconstruction of the Housesteads monument shows no eggshell but a crude rock alone. ${ }^{14}$

William K. C. Guthrie, in his seminal study on Orphism (1935), saw in the Modena relief an example "of syncretism between Orphic and Mithraic theology". ${ }^{15}$ In the same year (1935), Alda Levi tied the Modena relief to the so-called Lanx di Parabiago, a ritual silver plate unearthed in Parabiago near Milan in 1907 (CCCA 4: 268). ${ }^{16}$ The Parabiago patera shows Cybele and Attis in the company of the Corybantes and several cosmic deities like the Sun, Moon, Rivers, Seasons, Ocean, and Earth. Among others, there is a scene with a young athlete supporting the Zodiac wheel in which another youth stands to turn the wheel, and before them there is placed

\footnotetext{
${ }^{8}$ It is known, otherwise, that women were not excluded from the mysteries of Mithras, see BlOMART, A.: Mithra: quoi de neuf en 1990? JRA 9 (1996) 427-436, esp. 435; DAVID, J.: The Exclusion of Women in the Mithraic Mysteries: Ancient or Modern? Numen 47.2 (2000) 121-141; GRIFFITH, A.: Completing the Picture: Women and the Female Principle in the Mithraic Cult. Numen 53.1 (2006) 4877, esp. 61-62. fig. 909 .

${ }^{9}$ CoOK, A.: Zeus: A Study in Ancient Religion. Vol. 2.2. Cambridge 1925, 1051-1054 and

${ }^{10}$ Cumont, F.: Mithra et l'orphisme. RHR 109 (1934) 63-72 and pl. 1.

11 The current location of this inscription is following: Musei Capitolini, Centrale Montemartini, Magazzino, inv. MC 2981/S.

${ }^{12}$ GUARDUCCI, M.: II graffito NATUS PRIMA LUCE nel mitreo di Santa Prisca. In BIANCHI, U. (ed.): Mysteria Mithrae. Leiden 1979, 161.

${ }^{13}$ Relief from Housesteads (Borcovicus vel Vercovicium), dates from $253 \mathrm{AD}$ and is kept in the Newcastle Museum, inv. 1822.41.

${ }^{14}$ BosAnQUeT, R.: The Roman Camp at Housesteads (Borcovicus): Report on the Excavations in 1898. Newcastle-upon-Tyne 1904, 255-256 and fig. 28.

${ }^{15}$ Guthrie, W. K. C.: Orpheus and Greek Religion: A Study of the Orphic Movement. London 1935, 254-255 and pl. 12.

${ }^{16}$ Lanx di Parabiago dates from the 4th century AD and is kept now in the Civic Archeological Museum of Milan, inv. St. 5986. CCCA = VERMASEREN, M. (ed.): Corpus cultus Cybelae Attidisque. 7 vols. Leiden 1977-1989.
} 
a betyl entwined by a scaled serpent. Levi recognized in them, respectively, Atlas, Aion (as an alias for Mithras), and Chronos, the Mithraic time god. If we put all of them together, she says, we will have none other than the Modena god who combines these three elements into one: the Zodiac wheel, the young god inside, and the snake twisted around him. ${ }^{17}$

The interpretation of the same Lanx di Parabiago, as proposed by C. Albizzati (1937), is more sublime, that is to say: more Orphic. The scholar suggested that the position of the youth's hand between the Zodiac signs of the Ram and the Bull signifies the birth of Phanes, which took place around the cosmic month of Aries. Consequently, Albizzati interpreted the three figures as the first Orphic god-kings: the youth in the Zodiac is Phanes, deus principalis of the Orphic theology; the Atlas-like god is Uranus, the second king in the Orphic theology; and the serpent coiled around the betyl must be Cronus, the third king. It seems curious to me how, or why, in quoting so many Orphic parallels Albizzati omitted the most striking one: two lines of the prologue to the Orphic Hymns (vv. 28-29) that enumerate, among many other cosmic deities, Atlas and strong Aion together with ever-flowing Chronos. By analogy, Albizzati interpreted the Modena god, who has the attributes of Helios (solar crown on his head), of Men (a lunar crescent behind his shoulders), and of Zeus (a torch, i.e. a thunderbolt, he holds in his hand), as the Orphic Phanes. In addition, he observed that the god has bovine hoofs, which correspond to the one of epithets of

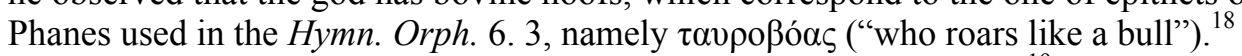

Hans Leisegang, in his famous study on the serpent cult (1939), ${ }^{19}$ compared the iconography of the Modena relief to an alabaster bowl, which was on its exterior decorated with figures of four winged trumpeters and inscribed with four Orphic verses. ${ }^{20}$ Unfortunately, the bowl in question has been lost (sold or stolen) in New

${ }^{17}$ LEVI, A.: La patera d'argento di Parabiago. Roma 1935, 9 and pl. 5.1.

${ }^{18}$ AlbizzATI, C.: La lanx di Parabiago e i testi orfici. Athenaeum 15 (1937) 190 n. 2, 191-193 and pl. 1.

${ }^{19}$ Leisegang, H.: The Mystery of the Serpent. Trans. R. Manheim. In The Mysteries [Bollingen Series 30.2]. New York 1955, 208-225 and pl. 3. [German original 1939].

${ }^{20}$ The first (and last) edition of the text is: DelBrueCK, R. - VOllgrafF, C.: An Orphic Bowl. JHS 54.2 (1934) 129-139. In my opinion, the text reproduced in Delbrueck and Vollgraff, should be ar-

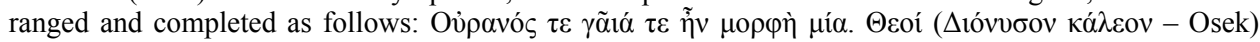

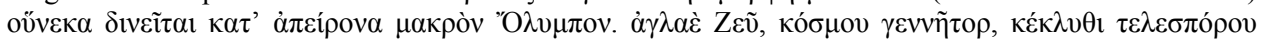

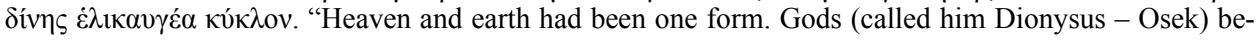
cause he rotates himself around infinite lofty Olympus. Oh dazzling Zeus, generator of the world, harken you whirling afar in circuit glowing!" (trans. Osek). The inscription contains three full verses from the

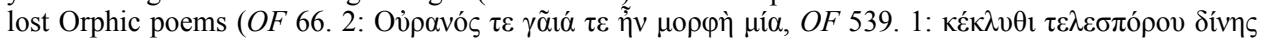

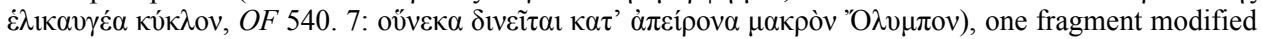

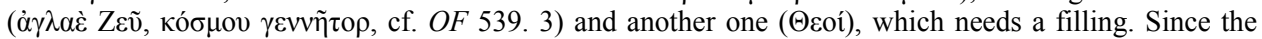

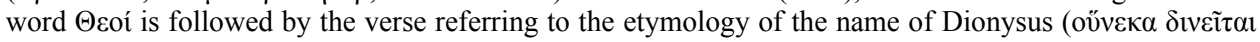
$\kappa \alpha \tau$ ' $\dot{\pi} \pi \varepsilon i ́ p o v \alpha \mu \alpha \kappa \rho o ̀ v ~ ' O \lambda v \mu \pi \mathrm{ov}$ ), it seems reasonable to me that the text may be supplied with the Orphic

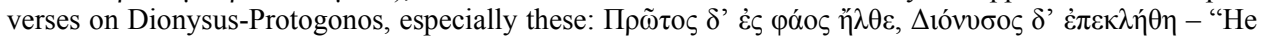

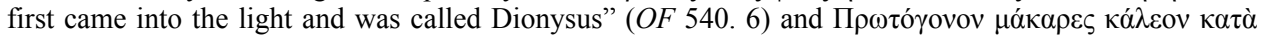

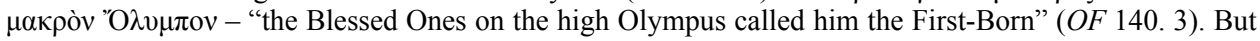
Attilio Mastrocinque suggested a different reading: "Hear (you who perennially turn) the radiant sphere of distant movement (which runs around the heavenly vortexes)! Heaven and earth were one form; (First he - Phanes - was born and named Dionysus), because he turns the infinite, the lofty Olympus in a round 
York City in 1957. Leisegang was of the opinion that both objects are similar to each other and purely Orphic. He held that the solar serpent inside the alabaster bowl was especially comparable with the snake twisted around the radiant body of the Modena god, and, then, that both of them may refer to Heracles, the serpentine monster ( $\delta \rho \alpha^{-}$ $\kappa \omega v \dot{\varepsilon} \lambda \iota \kappa \tau$ ćs), ${ }^{21}$ who was to deposit the cosmic egg of which the luminous PhanesPan came forth, according to one of the Orphic cosmogonies, the so-called theology of Hieronymus and Hellanicus. Next, he associated the Modena youth with the Orphic etymology of Pan that is found in Plato's Cratylus 408c (Pan is who "always moves", à $\varepsilon i ̀ n \lambda \tilde{\omega} v)$, and, furthermore, with the Hellenistic representation of Pan within a Zodiac circle (LIMC Pan no. 141). ${ }^{22}$

In his learned article on Aion (1944), Doro Levi reproduced many images, such as the Aion mosaic from Sentinum (LIMC Aion no. 13), the Mithras relief from Trier (CIMRM 985), the damaged Zodiacal statue from Arles (CIMRM 879), as well as the Modena relief, ${ }^{23}$ reducing them all to only one: Aion, the Graeco-Roman personification of eternity, as opposed to Chronos, time. Levi provides an excellent illustration of his point: the mosaic discovered in Antioch-on-Orontes, Syria, in 1939,

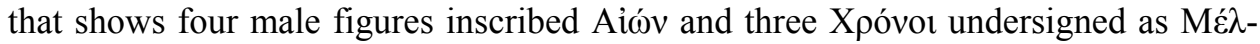

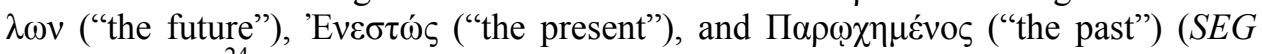
LVI no. 1857). ${ }^{24}$

Martin Nilsson (1945), following Guthrie (1935) and Levi (1944), takes the Modena monument to be a very interesting example of later ancient religious syncretism. ${ }^{25}$ The famous scholar uses the Orphic and Mithraic texts as well as the Chaldean and magical ones, to demonstrate that the Modena relief represents Aion, the cosmic god identical with the world and nature. Nilsson, in turn, was followed by Raffaele Pettazzoni (1949). ${ }^{26}$

René Dussaud (1950) pointed out that the Modena youth is a quite different god than the Mithraic leontocephaline (e.g. CIMRM 103, CIMRM 314), though both of them share a number of attributes, such as a serpent, huge wings, a lion head, a thunderbolt, a solar crown, and bovine legs. ${ }^{27}$

Maarten J. Vermaseren (1956) decided to include the Modena relief into his Corpus inscriptionum et monumentorum religionis Mithriacae (CIMRM 695-696), though he was aware of the syncretistic nature of the artifact. $^{28}$

circle; shining Zeus, generator of the cosmos." See MASTRocinQue, A.: From Jewish Magic to Gnosticism. Tübingen 2005, 197. OF = BERNABÉ, A. (ed.): Poetae epici Graeci: testimonia et fragmenta. Pars II: Orphicorum et Orphicis similium testimonia et fragmenta. Vol. 1. Monachii 2004.

${ }_{22}^{21}$ Athenag. Leg. pro Christ. 20. 1.

${ }^{22}$ J. BOARDMAN in LIMC VIII 1 (1997) 923-941, s.v. Pan.

${ }^{23}$ LEVI, D.: Aion. Hesperia 13.4 (1944) 290 and fig. 16, 299-301.

${ }^{24}$ Supplementum epigraphicum Graecum [SEG] LVI (2006) 605-606.

${ }_{26}^{25}$ NILSSON, M.: The Syncretistic Relief at Modena. SO 24 (1945) 1-7.

${ }^{26}$ Pettazzoni, R.: The Monstrous Figure of Time in Mithraism. In Essays on the History of Religions. Trans. H. J. Rose. Leiden 1967, 186-187 and pl. 10.8 [Italian original 1949].

${ }^{27}$ DuSSAUD, R.: Le dieu mithriaque léontocéphale. Syria 27.3-4 (1950) 259-260 and fig. 5.

${ }^{28}$ CIMRM (n. 4) 253-254 and fig. 197. 
Ugo Bianchi (1957 and 1975) also was inclined towards the syncretistic view, but made one reservation: the Mithraic deity to whom the Modena relief had been dedicated was not the time god Chronos (Cumont 1902) nor his Hellenized counterpart Aion (Levi 1944), but rather Arimanius, the guardian daemon, whose name is known from a headless York statue that has a legible dedication to Arimani $[o]$ $\left(C I M R M\right.$ 833). ${ }^{29}$ The statue in question was originally lion-headed; the head is missing but lion's mane is still visible. ${ }^{30}$ Bianchi agreed with Hans Leisegang (1939) that the Modena relief shows many analogies to the Orphic theology reported by Hieronymus and Hellanicus. ${ }^{31}$

Marcel Leglay, in his article on Aion in the Lexicon iconographicum mythologiae classicae (1981), reproduces a series of images that correspond to the Modena relief, which is included in the series under the number 17 (LIMC Aion no. 17*). ${ }^{32}$ The most interesting of these corresponding artifacts is a 3rd-century mosaic from Philippopolis; it shows a seminude man with the Zodiac ring, inscribed Aívv, in company of many cosmic personifications. Among others, Aion is accompanied by four

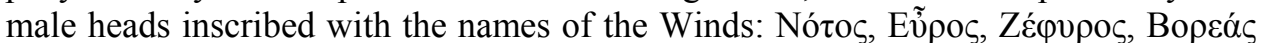
(LIMC Aion no. 3; cf. SEG XLIX no. 2104). ${ }^{33}$ Another parallel is provided by a gilded bronze statuette from Janiculum representing an Egyptian-looking idol coiled by a huge snake (LIMC Aion no. 21*). At the time of its discovery in 1908, the statuette was covered with the remains of seven eggs ("véritable omelette") deposited between seven serpentine coils. ${ }^{34}$ The Janiculum figurine was probably meant to represent Aion Agathodaimon ${ }^{35}$ or another Egyptian deity. ${ }^{36}$

In the 1980s there was a scholarly consensus that the Modena relief depicted a syncretistic divinity composed of Orphic, Mithraic, and Hellenistic elements, simultaneously representing Phanes, Mithras, Aion, and the lion-headed monster (whether he was called Chronos or Arimanius). The scholars spoke of "Orphic-Mithraic syncretism" (West 1983), "Mithraized Phanes" (Beck 1988) 38 and even of "a fluid Mithraic-Orphic-Aionic syncretism" (Ulansey 1989). ${ }^{39}$

${ }^{29}$ BIANCHI. U.: Protogonos: Aspetti dell'idea di Dio nelle religioni esoteriche dell'antichità. SMSR 28.1 (1957) 115-133; BIANCHI, U.: Mithraism and Gnosticism. In HinNELlS, J. (ed.): Mithraic Studies. Vol. 2. Manchester 1975, 465.

${ }^{30}$ MastrocinQue, A.: The Mysteries of Mithras: A Different Account. Tübingen 2017, 207 n. 5.

${ }^{31}$ BIANCHI: Protogonos (n. 29) 117.

${ }^{32}$ M. LEGLAY in LIMC I 1 (1981) 399-411, s.v. Aion.

${ }^{33}$ SEG XLIX (1999) 667.

${ }^{34}$ Goodhue, N.: The Lucus Furrinae and the Syrian Sanctuary on the Janiculum. Amsterdam $1975,33$.

${ }^{35}$ Cf. $P G M$ 4. 3170 where Aion is identified with Agathos Daimon, and PGM 12. 104-109: the prayer concerning the egg to Daimon Agathos who is the great Ammon. PGM= PREISENDANZ, K. ET AL.: Papyri Graecae Magicae. 2nd ed. 2 vols. Stuttgart 1973-1974.

${ }^{36}$ GOOdHuE (n. 34) 34-35, 62-63.

${ }^{37}$ West, M.: The Orphic Poems. Oxford 1983, 253-255 and pl. 8.

${ }^{38}$ BECK, R.: Planetary Gods and Planetary Orders in the Mysteries of Mithras. Leiden 1988, $58-59$.

${ }^{39}$ Ulansey, D.: The Origins of the Mithraic Mysteries: Cosmology and Salvation in the Ancient World. Oxford 1989, 120-124 and fig. 7.17. 
Based on the astronomical interpretation of the Mithraic iconography proposed by Roger Beck and David Ulansey, Maria Papathanassiou offered a full astronomical explanation of the Modena symbols (1991). ${ }^{40}$ Papathanassiou interpreted the four male heads in the corners as the winds or four elements; the Zodiac band as the world; the god-in-the-egg as Protogonos, Eros, and the Sun; the serpent around him as Chronos; the masks of the ram and he-goat as, respectively, the vernal equinox and winter solstice; whereas the middle head of the lion refers, in her opinion, to those astronomical data as they were in the remote past, i.e. in Sumerian times or four millennia before the Modena relief was made.

Günther Zuntz devoted two monographs to the god Aion in Graeco-Roman art and literature. In one of them (1991), ${ }^{41}$ he demonstrated that the Modena relief corresponds to the 2nd-century intellectual climate that can be exemplified by the hymn to Aion, both Night and Light, composed by Mesomedes in Hadrian's time (GDRK II no. 4). ${ }^{42}$ Howard Jackson (1994) traced the iconographic patterns of the Modena relief back to the 5th century BC and found a few striking parallels with the Attic vase paintings, namely the representations of Eros as a hoop-bowler. ${ }^{43}$ His point is that the Modena relief represents Eros, the god of cosmic love, who may be identified both with Phanes of the 2nd-century Orphic poetry and with the Hadrianic Aion who is represented on Hadrian's golden coins struck in 119-122 AD. The aureus shows a half-dressed man who stands inside the huge wheel, while he is reaching it with his right hand and holding in his left hand a globe with the bird Phoenix on its top. ${ }^{44}$

In 2010, the gem collection of Galleria Estense, including the Modena relief, was housed in Aosta, the Regional Archaeological Museum. The catalogue of that exhibit has the Modena god on its cover and contains an article by Nicoletta Giordani, the director of the Museo Lapidario at Modena. ${ }^{45}$ Giordani traces the fate of the Modena relief back to 1862 (its rediscovery by Celestino Cavedoni) and then to 1752, the year the Galleria Estense came to be in possession of the relief, but she is uncertain of how the relief came down to Modena and where it was kept before, though the history of the collection is very well documented in the files of the Bibliotheca

${ }^{40}$ PAPATHANASSIOU, M.: On the Astronomical Explanation of Phanes Relief at Modena. JHA 22 (1991) 1-13 and fig. 1.

${ }^{41}$ ZUNTZ, G.: AI $\Omega N$ im Römerreich: Die archäologischen Zeugnisse. Heidelberg 1991, 18-19.

${ }^{42} G D R K=$ HEITSCH, E. (ed.): Die griechischen Dichterfragmente der römischen Kaiserzeit. 2nd rev. ed. 2 vols. Götttingen 1963-1964.

${ }^{43}$ JACKSON, H.: Love Makes the World Go Round: The Classical Greek Ancestry of the Youth with the Zodiacal Circle in the Late Roman Art. In Hinnells, J. (ed.): Studies in Mithraism. Roma 1994, 131-132 and pl. 1 .

${ }^{44}$ On the other hand, Marie-Henriette Quet thinks that the interpretation of the male figure in question should be much simpler, in accordance with the inscription on the coin: SAEC AUR, which means saeculum aureum (“golden eternity”). See QUET, M.-H.: L'aureus au zodiaque d'Hadrien, première image de l'éternité cyclique dans l'idéologie et l'imaginaire temporel romains. Revue numismatique 160 (2004) $119-154$.

${ }^{45}$ SCAlini, M. - GIORDANI, N. (eds): Rinascimento privato: Aspetti inconsueti del collezionismo degli Este da Dosso Dossi a Brueghel: Aosta, Museo Archeologico Regionale, 12 giugno-1 novembre 2010. Milano 2010, 49-50 no. 1 . 
Estense. Drawing on the work of Adolfo Venturi (1883), ${ }^{46}$ Giordani supposes that before 1752 the relief had been kept in the palace of Marquis Sigismondo IV d'Este in San Martino in Rio, near Modena.

In 2014, Simona Cohen threw some light on the obscure history of the Modena relief before $1752 .{ }^{47}$ She pointed at three Renaissance monuments dating from 1524 to 1560 that are "free-style" copies of the Modena relief. They are found in north Italian cities: Padua (Odeo Cornaro, 1524), Florence (Palazzo Vecchio, 1544-1548), and Venice (Libreria Marciana, 1560), which implies the presence of the relief in San Martino in Rio since 1501 when the town became the center of an independent lordship for a cadet branch of the d'Este family. However, no one knows where the relief was before that date. To sum up, the provenance of the Modena relief, which was kept in San Martino in Rio (since 1501) and next in Modena (since 1752 up to today), is highly uncertain (Rome?), as is the identity of the egg-born god represented on it (Osiris?, Mithras?, Chronos?, leontcephaline?, Pantheus?, Aion?, Phanes?).

Attilio Mastrocinque is of the opinion that the Modena relief had been dedicated by a certain Mithraist, Felix Pater, as the inscription reads, and that the double PP may be explained as pater patrum ("father of the fathers") - the Mithraic title of the high priest. In accordance with this, Mastrocinque suggests a possible reading of the other inscription, which is obliterated, as syn[dex]i(us) or syn[dex]i(i) ("the initiated"). ${ }^{48}$ In his recent book The Mysteries of Mithras: A Different Account (2017), Attilio Mastrocinque discusses the iconography of the Modena relief. ${ }^{49}$ He remarks that among many images of the Mithraic Aion (a humanoid with lion's head), there are extant only two representations of the human-headed Aion. Mastrocinque indicates the Modena relief; the marble statue from Mérida, Spain (CIMRM 777), which was discovered together with the statue of the lion-headed figure with wings (CIMRM 776); and the lost relief from the house of Octavius Zeno, Rome (CIMRM 335), which had two Aiones, one winged and another wingless, standing among the seven fire altars and the solar and lunar chariots.

Mastrocinque argues, furthermore, that the Modena god can be identified as a Mithraic Aion, but in Mithraism there was a difference between the lion-headed Aion and the human-headed god, albeit both used to be called Aiones by convention. ${ }^{50}$ The Italian scholar proposes a conjectural reconstruction of the hierarchy of Mithraic gods. ${ }^{51}$ They were divided into the three hypercosmic gods and seven planetary gods: Saturn, Sol, Luna, Jupiter, Mars, Venus, Mercury, that were patrons of seven initiatory grades in the mysteries of Mithras: Pater, Heliodromus, Perses, Leo, Miles, Nymphs, Corax. The hypercosmic gods, in Mastrocinque's view, seem to be rather hypostases of one god than three different gods, because they were very similar

${ }^{46}$ Venturi, A.: La R. Galleria Estense in Modena. Modena 1883, 329, 363 fig. 94.

${ }^{47}$ COHEN, S.:Transformations of Time and Temporality in Medieval and Renaissance Art. Leiden 2014, 9 fig. 2, 19-25, 275-78 and fig. 124.

${ }_{48}$ MASTROCINGUE: Studi (n. 2) 102-104, esp. 102 n. 351.

${ }^{49}$ MASTROCINQUE: The Mysteries (n. 30) esp. 211 fig. 58, 213-214, 225-227.

${ }^{50}$ MastrocinQue: The Mysteries (n. 30) 210.

${ }^{51}$ MASTROCINQUE: The Mysteries (n. 30) 205, 252. 
to each other and their virtues were mirrored in three upper planetary gods, i.e. Saturn, Sol and Luna. The first and highest of the pantheon was to be Aion, alias Arimanius, represented in art as the well-known leontocephaline ("lion-headed"). The second in hierarchy was Mithras who usually bears the solar attributes; and the third was called Horomazes and was depicted as a beautiful young man constrained by a snake and bearing a lion's head on his chest. The Modena relief and the statue from Mérida are the only representations of the youngest god of the hypercosmic triad. Since the young god corresponds with the position of Luna, he is represented in the Modena relief as equipped with lunar attributes. ${ }^{52}$

Besides, Mastrocinque discusses the Orphic theology reported by Hieronymus and Hellanicus and transmitted by Athenagoras in the 2nd century AD and Damascius in the 6th century AD. He finds it compatible with the system of Mithraic gods, especially the hypercosmic triad, and he thinks that Chronos Heracles, the first god according to Hieronymus, was the Orphic counterpart of the Mithraic Aion Arimanius, whereas Zeus Pan, who according to the same version of the Orphic theology was born from the cosmic egg laid by Chronos Heracles, can be equated with Horomazes. The Orphic influence upon Mithraism has been widely presented and scrutinized by Mastrocinque. ${ }^{53}$ His conclusion is that the Modena relief represents the syncretistic god linking the Mithraic pantheon with the Orphic theology and it was dedicated by some Mithraists in Rome to Zeus Pan (Phanes?) Horomazes.

Finally, Raffaella Bortolin (2012) compiled an iconographic corpus on all representations of "Leontocefalo", that have been preserved from the Graeco-Roman antiquity, 52 images in total. ${ }^{54}$ She included in the corpus both the Modena relief and the Mérida statue, as the only extant representations of the leontocephaline god with a human head. The Modena relief, in her opinion, represents the Mithraic god of eternal time, albeit some influences of the Orphic theology on it can be traced. ${ }^{55}$

\section{SOME NOTICED PARALLELS WITH THE ORPHIC THEOLOGY BY HIERONYMUS AND HELLANICUS}

The so-called theology of Hieronymus and Hellanicus (who probably were the same person $^{56}$ ) has been transmitted by two independent sources dating from 177 AD (Athenagoras, Legatio pro Christianis) ${ }^{57}$ and 515 AD (Damascius, De primis princi-

${ }^{52}$ MASTROCINQUE: The Mysteries (n. 30) 252.

${ }^{53}$ MASTROCinQue: The Mysteries (n. 30) 209, 215, 216-219, 223-226.

${ }_{55}^{54}$ BORTOLIN, R.: Il leontocefalo dei misteri mitraici: l'identità enigmatica di un dio. Padova 2012.

${ }_{55}^{55}$ BORTOLIN (n. 54) 97-100, 232-234 no. 44, 188-192.

${ }^{56}$ This is a remark made by Damascius, see $O F 69=O F 1138$. The story may be attributed to several Hellenistic writers and works: Hieronymus the Egyptian, Phoenician Antiquities, FGrHist 787 F 3; Hieronymus of Rhodes, On Poets, fr. 61 White; Hellanicus of Lesbos, Theology, frs. 18 B + 202A Fowler; Hellanicus of Lesbos, Phoronis, FGrHist $4 \mathrm{~F} 87$. Anyway, none attribution is sure.

${ }^{57}$ Athenag. Leg. pro Christ. 18. $4-20.3=O F 75 \mathrm{ii}, O F$ 76ii, $O F$ 76iii, $O F$ 82ii, $O F$ 79ii, $O F$ 80ii, OF 81, $O F$ 80iii, $O F$ 85, $O F$ 82i, $O F$ 83, $O F$ 84, OF 87i, $O F$ 89i. 
piis $),{ }^{58}$ alluded to by Gregory of Nazianzus, ${ }^{59}$ and summarized by Basil Elachistos, the 10th-century scholiast. ${ }^{60}$ This theology is credited to Orpheus, the poet, and Athenagoras quoted eight metrical verses, ${ }^{61}$ to authenticate his authorship.

The story consists of ten episodes. (1) At the beginning of the world, there was nothing but primordial water and primeval mud, personified as Ocean (male) and Tethys (female); out of the latter the earth was moulded. (2) These two principles, water and mud, engendered Chronos Heracles, the ageless serpent or dragon. He was equipped with a pair of wings and three heads: of a lion, of a young god, and of a bull grown out of his body. (3) Chronos Heracles married Adrasteia Ananke, the twobodied goddess of necessity who encompassed the whole world. (4) Chronos Heracles mated with himself - not with his wife - and begot Ether, Chaos, and Erebos. In the midst of them, he deposited the double-sexed dragon egg. (5) When the eggshell was broken, its upper half became heaven, whereas the lower part was transformed into the earth. (6) Besides, the same egg produced the third god: Phanes Protogonos. He, or she, had golden wings, two bodies with many bovine heads growing out of them, and wore a uraeus, a snake crown, on his head. (7) The two-sexed Phanes Protogonos begot by himself Echidna, a half-maiden and half-serpent daughter. (8) The egg halves became great deities: Heaven (male and upper) and Earth (female and lower). They married each other and gave birth to many divine generations. All children of Heaven and Earth were serpents, because they descended from Chronos Heracles, the dragon. (9) One of them, Zeus, who was a serpent too, swallowed Phanes Protogonos to become Pan, or the universe. (10) Afterwards Zeus Pan married his mother Rhea, the viper, and fathered Phersephassa Athela, the she-dragon similar to Phanes in being a two-bodied and four-eyed monster. Zeus Pan mated with Phersephassa Athela to beget Dionysus, the dragon.

The episodes are inconsistent in a few points. The author referred to the genesis of Heaven and Earth three times (episodes 1, 5, 8); gave Chronos Heracles a wife, albeit the two-sexed dragon needed no partner to reproduce himself (episodes 3 and 4 ), and introduced two creators of the world: Chronos Heracles, the father, and Phanes Protogonos, the son, who are very similar to each other (episodes 2 and 6). The former one is to create the cosmos, whereas the latter one is to be swallowed by Zeus who wanted to become the king of the universe (episodes 4 and 9). The story looks like an Orphic text, but actually it is un-Orphic theology that contradicts the Orphic doctrine of one god in all and of priority of Phanes who was the first god (not the third god!).

Attilio Mastrcinque (2017), following Ugo Bianchi (1957), noticed the several points of convergence between the theology of Hieronymus and the iconography of the Modena relief. The Modena relief, he argues, depicts the young god as entwined

\footnotetext{
${ }^{58}$ Dam. De primis principiis 123. 2 (Westerink 3: 160-162) $=$ OF 75i, OF 76i, OF 77, OF 78, OF 79i, OF 80i, OF 86.

${ }^{59}$ Gr. Naz. Or. 4. $115=$ OF 848ii; Gr. Naz. Or. 31. 16=OF 191 ii.

${ }^{60}$ NordEN, E.: Scholia in Gregorii Nazianzeni orationes inedita. Hermes 27.3 (1892) 614-615. See also $O F$ 191ii, $O F$ 76iv, $O F$ 79iii, $O F$ 80iv.

${ }^{61}$ OF 81, OF 83.
} 
by the snake posing its head on his head, which resembles Phanes Protogonos as described by Hieronymus (cf. episode 6). The snake around his body is obviously Chronos Heracles, his father, who deposited the cosmic egg (cf. episode 4), which is shown on the Modena relief, too. We can see three animal heads growing out of the body of Modena god, and we read about the multiplicity of divine heads in Hieronymus (cf. episodes 2 and 6). The Modena god has beautiful wings, just like Phanes Protogonos equipped by Hieronymus with a pair of golden wings (cf. episode 6). The lunar attributes of the Modena god (a crescent behind his shoulder, goat's hooves) result from the divine name of Pan, which was bestowed on Zeus after swallowing Phanes Protogonos (cf. episode 9), and the Modena god looks like the cosmic Pan whose upper part was that of a god and the lower one that of a he-goat to symbolize, respectively, the sky and the earth (cf. Apollod. FGrHist 244 F 134c). After all, the Mithraic lion-headed Aiones correspond to the description of Chronos Heracles given by Hieronymus (cf. episode 2), and the serpent coupled with the lion-headed Aion is paralleled by Adrasteia Ananke, his consort, according to Hieronymus (cf. episode 3). ${ }^{62}$ Mastrocinque concludes that "the founder of the mysteries of Mithras used an Orphic text similar to that of the cosmogonies of Hieronymus and Hellanicus.",63

I absolutely agree with Mastrocinque' standpoint that in the 2nd century AD there were some interrelations between Orphism and Mithraism, and that the theology of Hieronymus and Hellanicus provides us with a piece of evidence for such relation. But this variant of the Orphic theology cannot explain the other details of the Modena relief, such as the positioning of the Zodiac band, the occurrence of four Winds, the arrangement of the staff and the torch in the god's hands.

\section{SOME UNNOTICED PARALLELS WITH THE ORPHIC RHAPSODIES}

Martin L. West was the first to remark on the Modena relief that the Orphic element in it is based on the Orphic Rhapsodies, ${ }^{64}$ but he did not specify the details.

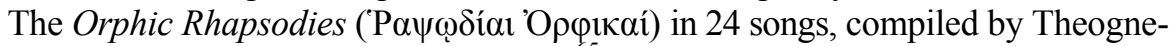
tus of Thessaly or Cercops the Pythagorean, ${ }^{65}$ are a lost and extremely controversial poem as regards its title, the date of composition, the authorship, and the attribution of particular fragments to it. We know for certain that the poem contained "the standard Orphic theology"66 - in contrast to "unorthodox" theology of Hieronymus and Hellanicus - which was alluded to by many writers, poets, and artists since ca. $100 \mathrm{AD}$ onward, and that the poem was read and studied until the end of antiquity (565 AD). Although the hexametric lines extant from the Orphic songs date from

\footnotetext{
${ }^{62}$ MASTROCINQUE: The Mysteries (n. 30) 216-226.

${ }^{63}$ MASTROCINQUE: The Mysteries (n. 30) 223.

${ }^{64}$ WEST (n. 37) 255.

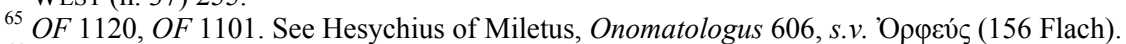

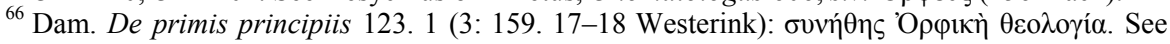
also $O F 96$ and $O F 677 \mathrm{i}$.
} 
200-565 AD and there is no evidence for the existence of the poem before $100 \mathrm{AD},{ }^{67}$ scholars generally incline to the opinion that the Orphic Rhapsodies might be composed as early as ca. $100 \mathrm{BC}^{68}$ The most complete edition of the fragments is the one included in Orphicorum et Orphicis similium testimonia et fragmenta by Alberto Bernabé (2004), ${ }^{69}$ which hereafter will be abbreviated $O F$. Speaking of "the most complete", I mean "almost complete", because the Bernabé edition is missing a number of fragments that should be included in it.

In my opinion, there are some episodes in the reconstructed narrative of the $\mathrm{Or}$ phic Rhapsodies, which should be discussed in the context of the iconography of the Modena relief. These episodes concern the Orphic god Phanes and they are following:

\section{The god who integrates the cosmic egg}

According to the summary of the Orphic Rhapsodies that appears in the PseudoClementines (ca. 200 AD), the entity called Phanes ("Who First Appeared") and Protogonos ("First Born One") hatched out of a cosmic egg that had been laid by Chronos ("Time") in the darkness of Aither ("Ether"). "Since the capacious egg was broken in

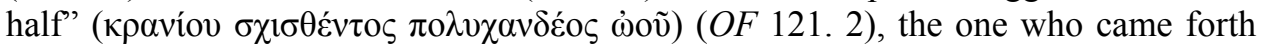
has held together the two halves ( $O F$ 121iii), of which the upper one stands for the heavens and the lower one for the house of Hades. ${ }^{70}$ Note that the Modena god integrates two halves of the cosmic egg, as does Phanes, and that the egg is inverted, i.e. the conic eggshell is beneath the god's hoofs (cf. fig. 5), as is suggested in the quoted text. Otherwise we know that the god in question was called, in the Orphic Rhapso-

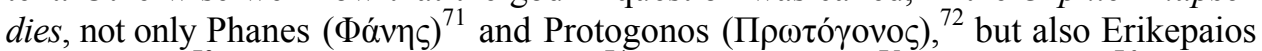

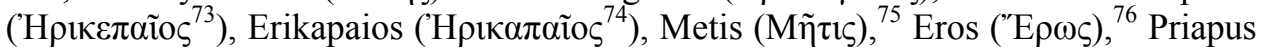

\footnotetext{
${ }^{67}$ BRISSON, L.: How Philosophers Saved Myths: Allegorical Interpretation and Classical Mythology. Trans. C. Tihanyi. Chicago 2004, 96-97.

${ }^{68}$ WeST (n. 37) 251; Bernabé, A.: The Gods in Later Orphism. In BREMMER, J. - ERSKInE, A. (eds): The Gods of Ancient Greece: Identities and Transformations. Edinburgh 2010, 423.

${ }^{69}$ BERNABÉ: Poetae epici Graeci (n. 20) 97-295.

${ }^{70}$ OF 121iii + OF 121. $2+$ OF $171+$ OF $203 \mathrm{i}=$ Pseudo-Clem. Hom. 6. 6. 1-3: "This egg, then, which was the first substance, growing somewhat hot, was broken by the living creature within, and then there took shape and came forth something; such as Orpheus also speaks of, where he says, "when the capacious egg was broken,' etc. And so by the mighty power of that which appeared (phaneis) and came forth, the Globe attained coherency, and maintained order, while it itself took its seat, as it were, on the summit of heaven, there in ineffable mystery diffusing light through endless ages. But the productive matter left inside the globe, separated the substances of all things. For first its lower part, just like the dregs, sank downwards of its own weight; and this they called Pluto from its gravity, and weight, and great quantity (poly) of underlying matter, styling it the king of Hades and the dead" (the ANF translation).

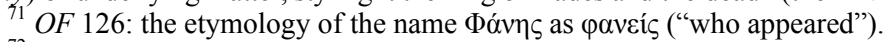

${ }^{72}$ OF 125.

${ }^{73} O F 134$ (the androgyne: both male and female); $O F$ 143. 4; $O F$ 167. 2; $O F$ 170; $O F$ 241. 1.

${ }^{74}$ OF 134v; OF $162 \mathrm{i}+$ OF $200 \mathrm{ix} ; O F 139 \mathrm{v}=O F 107 \mathrm{ii}$.

${ }^{75}$ OF 138. 2 ("Metis the seed-bearer"); $O F$ 140. 2; $O F$ 245. 4 ("Metis the foremother").

${ }^{76}$ OF 100. 4 ("the elder Eros"); $O F 144$ ("the blind Eros"); $O F$ 245. 4 ("Eros the joy-maker").
} See also: GILBERT, C.: Blind Cupid. JWI 33 (1970) 304-305. 


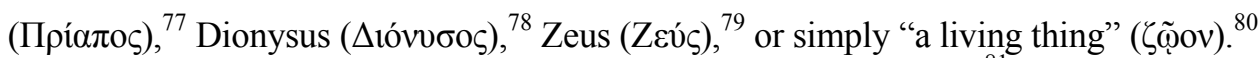
$\mathrm{He}$ (actually, he-and-she) had been absolutely the first living being ${ }^{81}$ and the supreme god. $^{82}$

\section{The Winds}

We are told that Eros (a Rhapsodic name of Phanes) had brothers who were winds:

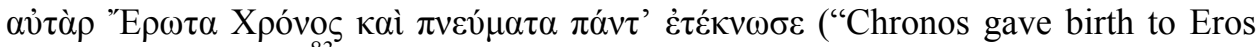
and all the Winds"). ${ }^{83}$ The quotation, which comes down from the Orphic Rhapsodies through the late ancient scholiast, provides a striking parallel with the Modena relief that has four heads of Winds placed in the corners.

\section{The golden wings}

The later Neo-Platonist Hermias of Alexandria transmitted the following verse from

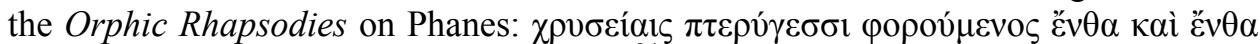
("Flying go and fro on his golden wings"). ${ }^{84}$ The golden wings are to symbolize the eternal movement of god who is the son of Aither, ${ }^{85}$ the ever-moving one. ${ }^{86}$ The Modena relief provides us with a fine illustration of this attribute of Phanes.

\section{Four mystic animals}

The Orphic Rhapsodies claim that the most mysterious feature of Phanes is being $\tau \varepsilon \tau \rho \alpha \pi \rho \sigma^{\circ} \sigma \omega \pi$ ov ("four-faced"), ${ }^{87}$ which was allegedly alluded to in the book of Ezekiel $1: 6-10{ }^{88}$ The faces belong to four mystic animals that the god bears on his fiery

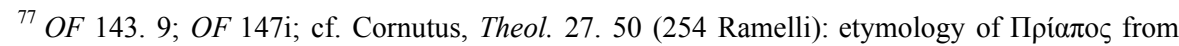
$\pi \rho$ óєı๐ı ("proceeds" towards the light).

${ }^{78}$ OF 140xi ("Dionysus himself is often called Phanes and Erikepaios"); $O F$ 540. $7=O F$ 540ii

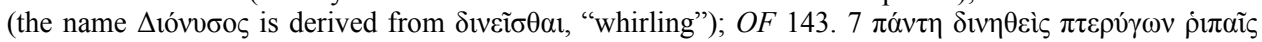

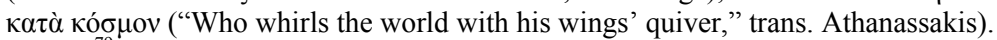

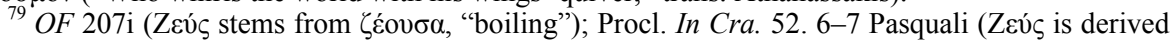

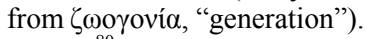

${ }^{80}$ OF 120iii; $O F 121$ vi.

${ }^{81} O F$ 121v: $\pi \rho \omega ́ \tau 1 \sigma \tau o v ~ \zeta \tilde{\omega}$ ov ("the primeval animal"). Phanes").

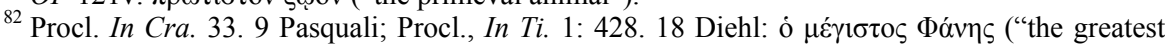

${ }^{83}$ OF $360=$ Schol. in Apollonii Rhodii Argonautica 3.26a (216 Wendel), trans. Osek.

${ }^{84}$ OF $136=$ Herm. In Phdr. 148. 25 Lucarini-Moreschini, trans. Osek.

${ }^{85}$ OF 125.

${ }^{86}$ OF $118+$ OF 119

${ }^{87} \mathrm{OF} 133 \mathrm{~b}$.

${ }^{88}$ It was the Church father Theodoret of Cyrus who associated the four mystical animals (human, lion, bull, eagle) from the book of Ezekiel with the Rhapsodic $\tau \varepsilon \tau \rho \alpha \pi \rho \sigma^{\circ} \sigma \omega \pi \mathrm{ov}$ (Theodoretus Cyrensis, In Ezech. 1, PG 81, 825A). See BERNABÉ: Poetae epici Graeci (n. 20) 134. 
body. These are: a ram, a serpent, a lion, and a bull. ${ }^{89}$ This feature of the Rhapsodic Phanes corresponds to the Modena god, who appears in the company of animals that grow on or entwine his divine body. These include the three heads attached to the god's chest and the serpent twisting around his silhouette in four coils, which can be associated with the tetractys (both four and ten) - the number sacred to Phanes. ${ }^{90}$

\section{Solar-and-lunar attributes}

The Orphic Rhapsodies represent Phanes as a kind of mystic light which is invisible itself but, at the same time, makes the other things visible. ${ }^{91}$ The texts inspired by the Orphic Rhapsodies speak of "the true light which illuminates every man as he comes into the world," and "the light of the world" that "we can see with his radiance, not with our eyes." 92 It was stated, too, that Phanes, the first light, was united with his consort Nyx ("Night"). ${ }^{93}$ The pair of gods begot Uranus ("Heaven") and Gaia ("Earth"), who, in turn, gave birth to minor cosmic gods, including Helios ("Sun") and Selene ("Moon"). ${ }^{95}$ The younger gods became avatars of the first parents, by saving the family likeness: Helios to Phanes and Selene to Nyx. ${ }^{96}$ Likewise, the Modena god wears both solar attribute (a fire-crown on his head) and lunar one (a crescent behind his shoulders).

\section{A scepter}

The Modena god holds a long staff in his hand as does Phanes who is said in the

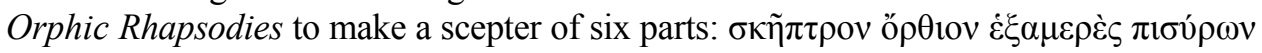

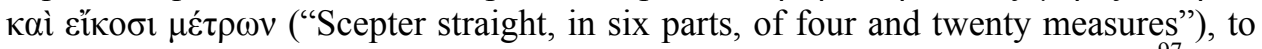
symbolize his control over world history, which falls into six divine kingdoms. ${ }^{97}$ This

${ }^{89}$ OF $129 \mathrm{i}=$ Procl. In Ti. 1: 429. 26-29 Diehl: "This is why the Theologian fashions a most universal living thing, placing on it the heads of a ram, a bull, a lion and a serpent" (trans. Runia and Share); OF 130 = Procl. In Ti. 1: 427. 21-24 Diehl: "And in fact Orpheus presents a similar picture of [the Living-Thing itself] in his theological writings on Phanes. At any rate, in [Orpheus], this god first wears many animal heads, 'emitting the bellows of a bull and the roars of a fierce lion'," (trans. Runia and Share).

${ }^{90}$ Nicom. in Pseudo-Iambl. Theologia Arithmeticae 10 (80 Falco): tetractys, the universe, the sun, the god, and Phanes are synonyms.

${ }^{91}$ OF 149ii + OF 123i + OF $123=$ Herm. In Phdr. 155. 4-13 Lucarini-Moreschini.

92 John 1:9 and 8:12; OF $161=$ Corpus Hermeticum fr. 23 Nock.

${ }^{93}$ OF 123i; $O F 148$ ii; $O F 175 \mathrm{i}$.

94 OF 149.

${ }^{95}$ OF 155-158.

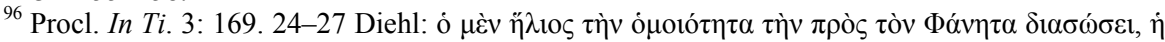

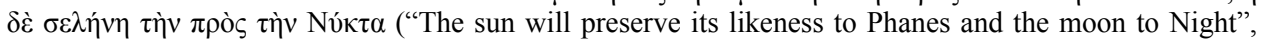
trans. Tarrant). The fragment has been not included into the Bernabé edition, but it is found in: W. FAUTH. Helios Megistos: Zur synkretistischen Theologie der Spätantike. Leiden 1995, 220 no. 105.

${ }^{97}$ OF 166 (trans. West); cf. OF 98iii. 
scepter makes every next god that takes it over (Phanes, Nyx, Uranus, Cronus, Zeus, Dionysus) a kosmokrator ("ruler of the world"). ${ }^{98}$

\section{The Zodiac band}

Phanes was identified with Priapus, ${ }^{99}$ who was often mingled with the sun and the Egyptian god Horus ( $\left.{ }^{2} \Omega \rho o \varsigma\right) .{ }^{100}$ The latter one was, in turn, the personification of a year, which encompasses four seasons and tropic signs. ${ }^{101}$ One may suppose that Phanes Horus was to signify not a solar year but the so-called Great Year that according to the Orphic beliefs consists of 120,000 solar years. ${ }^{102}$ Moreover, the Rhapsodic Phanes was credited with writing his prophecies concerning world history, and

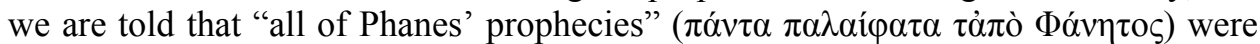
incorporated into book four of the Orphic Rhapsodies. ${ }^{103}$ In addition, the poet Nonnus provides us with a recapitulation of what Phanes prophesied. In his Dionysiaca, Nonnus describes six diptychs marked with the Zodiac signs (or twelve tablets in sum), which had been engraved by the hand of Phanes and deposited in Helios' palace, and he summarizes the contents of seven tablets (of a total number of twelve). ${ }^{104}$ Undoubtedly, the poet of Panopolis must have drawn on the Orphic Rhapsodies, though Alberto Bernabé decided against including the Nonnian passage into his edition of the Orphic Rhapsodies. These summaries, completed by Viktor Stegemann with the material from the Dionysiaca, ${ }^{105}$ go as follows:

Diptych I: graphis 1 (saeculum of Aries) contains the reigns of the primordial deities: Ophion and Eurynome, or Uranus and Gaia; graphis 2 (Saeculum of Taurus) represents the castration of Uranus and the succession of Cronos.

Diptych II: graphis 3 (saeculum of Gemini) shows the rise of tree-born men, the dethronement of Cronos succeeded by Zeus, and the birth of Zagreus from Zeus and Persephone; graphis 4 (saeculum of Cancer) comprises the reign of Zagreus, the baby god-king, and his assassination by the Titans, and the cosmic flood that Zeus sent to take revenge on them.

${ }^{98}$ OF 167 (Phanes rex); OF 168 (Nox regina); OF 174 (Caelus rex); OF 190 (Saturnus rex); OF 243.5 (Hymnus in Iovem); OF 299 (Bacchus rex).

${ }^{99}$ See n. 77.

${ }^{100}$ Chaeremon fr. 18D Horst: "Priapus: the statue of Priapus, who is called Horus among the Egyptians, is made in human form, holding fast a scepter in his right hand as if the dry land and the sea appear through him. In his left hand he holds the penis in erection because he makes visible the seeds that lie hidden in the earth. The feathers (symbolize) the speed of his motion; the circle of the disk (symbolizes) his revolution. For they identify him with the sun" (trans. Horst).

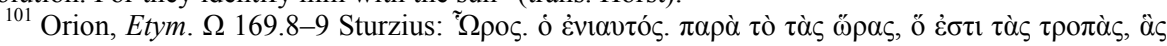
$\pi \varepsilon \rho t \varepsilon ́ \chi \varepsilon 1$ ("Horus: a year; in addition to the seasons, i.e. the tropic signs, that he encompasses," trans. Osek).

102 OF 358 i.

${ }^{103}$ OF $138=$ Theosoph. Tubing. 61 (44 Erbse).

${ }^{104}$ Nonnus, Dion. 12.31-113.

${ }^{105}$ Stegemann, V.: Astrologie und Universalgeschichte: Studien und Interpretationen zu den Dionysiaka des Nonnos von Panopolis. Leipzig 1930, 197-199. 
Diptych III: graphis 5 (saeculum of Leo) is to show a new race of humans, the earth-born ones who inaugurated the Iron Age, and the birth of Dionysus, their savior; graphis 6 (saeculum of Virgo) depicts the metamorphoses of Dionysus' friends: of Ampelos into a vine, of Kissos into an ivy branch, and of Kalamos into a reed.

Diptych IV: graphis 7 (saeculum of Libra) narrates the way in which Dionysus became the patron of wine.

Of these cosmic events, the rise of tree-born men that took place at the sign of Gemini deserves our attention, since the Modena god illuminates Gemini with his torch. On the other hand, the god indicates with his scepter the sign of Pisces that falls outside the narrative of the Dionysiaca (it would have been shown on diptych VI, graphis 12). The gesture of pointing towards Pisces is paralleled by two Aion mosaics, one from Ammaedara in Tunisia (LIMC Aion no. 15) and another from Sentinum (LIMC Aion no. 13), therefore it cannot be meaningless. Presumably it signifies the last age of human history because Aries marked the beginning of the Great Year, as Albizzati ingeniously remarked. ${ }^{106}$

To sum up, the Modena god, who stands in the Zodiac oval and is oriented according to four tropic signs (Aries, Cancer, Libra, Capricorn), is comparable with the role that the Orphic Rhapsodies attribute to Phanes Horus as a personification of the Great Year. The positions of his torch and scepter may refer to the rise of the tree-born men in the cosmic month of Gemini and the end of the world at Pisces - references to both these cosmic events were made in the Orphic Rhapsodies.

\section{THE MODENA RELIEF AND \\ THE INTERPRETATIO PLATONICA OF MITHRAS}

As concerns the arrangement of the Zodiac signs, the closest parallel with the Modena relief is provided by the Numenian passage transmitted by Porphyry of Tyre in his Cave of the Nymphs 21-29 and by two later writers: Proclus (Procl. In R. II 128. 26 - 130. 2 Kroll) and Macrobius (Macrob. In Somn. 1. 11. 10 - 1. 12. 12). ${ }^{107}$

The question of whether the passage is totally "Numenian" is problematic, since Porphyry utilized not only Numenius' work On Immortality of the Soul, but also "his

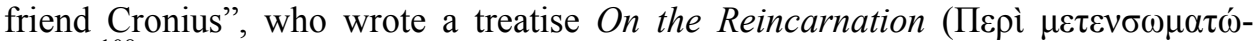
$\sigma \varepsilon \omega \varsigma){ }^{108}$ both works have been lost. Moreover, the Middle-Platonists incorporated

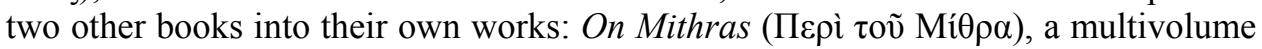

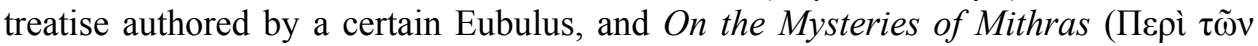

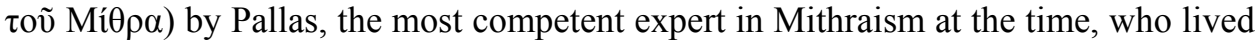

\footnotetext{
${ }^{106}$ AlbizZATi (n. 18) 190 n. 2.

${ }^{107}$ LEEMANS, E.-A. (ed.): Studie over den wijsgeer Numenius van Apamea: met uitgave der fragmenten. Bruxelles 1937, 147-152.

${ }^{108}$ Cronius fr. 12 Leemans: "Cronius in his work on reincarnation, which he calls metensomatosis, says that all souls are rational” (trans. Osek).
} 
during the reign of Hadrian (117-138 AD) ${ }^{109}$ Perhaps these two books on Mithras were contemporaneous with Plutarch's treatise On Isis and Osiris 46 (369E), where Mithras is mentioned as $\mu \varepsilon \sigma i$ in $\zeta$. Therefore, it is hard to say whether Porphyry, to whom we owe all extant fragments from Eubulus and Pallas, derived directly from them or whether, as Robert Turcan supposes, ${ }^{110}$ he drew on second-hand quotations given by Numenius and Cronius.

The famous excerpt in Porphyry's Cave of the Nymphs 21-29 ${ }^{111}$ goes as follows:

"(21) Taking the cave as an image and symbol of the Cosmos, Numenius [fr. A 3 Leemans] and his pupil Cronius [fr. A 1 Leemans] assert that there are two extremities in the heavens: the winter tropic than which nothing is more southern, and the summer tropic than which nothing is more northern. The summer tropic is in Cancer, the winter tropic is in Capricorn. Since Cancer happens to be closest to us upon earth, it has, with good reason, been assigned to the Moon, which is nearest to the earth; since the southern pole is as yet invisible to us, Capricorn has been assigned to Saturn, the most remote and highest of the planets. (22) The signs of the Zodiac, in fact, are situated in this order: from Cancer to Capricorn we have, first of all, Leo, which is the house of the Sun; then Virgo, the house of Mercury; Libra, the house of Venus; Scorpio, the house of Mars; Sagittarius, the house of Jupiter; and Capricorn, the house of Saturn. Then from Capricorn back, Aquarius has been assigned to Saturn; Pisces to Jupiter; Aries to Mars; Taurus to Venus; Gemini to Mercury; and finally, Cancer to the Moon. ${ }^{112}$ The theologians spoke of these, Capricorn and Cancer, as two gates; and Plato called them orifices [Pl. Resp. 614c]. Of these Numenius and Cronius say that the gate through which souls descend is Cancer, but that they ascend through Capricorn. And Cancer is northerly and suited for descent, while Capricorn is southerly and suited for ascent. ${ }^{113}$ (...) (24) Homer, then, did not have the cave's entrance dedicated to the east or west or to the equinoctial points - Aries and Libra, but to the north and south and to the gates of the heavens furthest north and south, because the cave was sacred to souls and water-nymphs; and for souls these regions are proper to genesis and departure from genesis. The equinoctial region they assigned to Mithras as an appropriate seat. And for this reason he bears the sword of Aries, the sign of Mars; he also rides on a bull, Taurus being assigned to Venus. As

\footnotetext{
${ }^{109}$ Porph. Abst. 2. 56. 3: "Pallas, who wrote, in the reign of emperor Hadrian, the best account on the mysteries of Mithras, says that human sacrifice had been abolished almost everywhere" (trans. Clark).

${ }_{110}$ TURCAN, R.: Mithras Platonicus: recherches sur l'hellénisation philosophique de Mithra. Leiden 1975, 26-27.

${ }_{111}$ Porphyry: The Cave of the Nymphs in the Odyssey. Buffalo, NY 1969, 21-29 [the Arethusa text and translation].

${ }_{113}^{112}$ Numen. De immortalitate animae fr. B 43 Leemans.

${ }^{113}$ LEEMANS (n. 107) 150.
} 
a creator and lord of genesis, Mithras is placed in the region of the celestial equator with the north to his right and the south to his left; to the south, because of its heat, they assigned Cautes and to the north $<$ Cautopates $>$ because of the coldness of the north wind. ${ }^{114}$ (...) (28) Also, he [sc. Numenius] speaks somewhere of 'the gates of the Sun,' meaning Cancer and Capricorn. For the Sun advances to these regions, descending from the north to the south and from there ascending to the north. Capricorn and Cancer are close to the Milky Way, occupying its extremities Cancer to the north and Capricorn to the south. (...) 'The land of dreams' [Hom. Od. 24. 12], according to Pythagoras, is composed of souls, which are gathered into the Milky Way; and the Milky Way is named from the milk with which these are nourished when they have fallen into genesis. This is the reason why those who summon up souls pour libations of honey mixed with milk, in as much as souls have formed the habit of proceeding to genesis by the allurement of pleasure - and milk is naturally generated with birth. ${ }^{115}$ (29) Plato says that there are two orifices, one through which souls ascend to the heavens, the other through which they descend to earth [P1. Resp. 614d-615e]; and the theologians [cf. Pherec. D-K 7 B 6] make the Sun and Moon gates for souls, and say that they ascend through the Sun and descend through the Moon. ${ }^{116,}$

Why were the Middle Platonists more interested in the Mithraic iconography and mysteries than in other ones? Because they found the Mithraic symbols and rites to be similar to Plato's doctrine of the soul. The imagery of the cave is a prime example; it can be found both in Plato (Resp. 514a-520a) and in a mithreum. Therefore, these Middle Platonists had no doubt that in both cases the cave was to symbolize the universe, and whatever was to be found inside was to signify the elements of the world. ${ }^{117}$ Numenius was convinced that the Persian mystagogues initiated their candidates in grottoes and explained to them the downward journey of souls and their

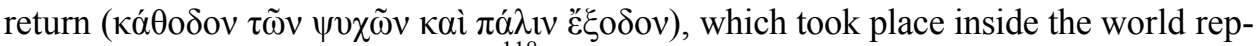
resented by the image of the cave. ${ }^{118}$

Moreover, Numenius tried to complete, or develop, Plato's theory of the soul. First, he specified the location of the stars to which the human souls were allotted: this was to be the Milky Way ( $\gamma \alpha \lambda \alpha \xi i \alpha)$, from which every human soul came down to earth. ${ }^{119}$ Secondly, he thought that the incorporeal soul that descends from the Milky Way to the earth must pass through the seven planetary spheres and don a kind of ethereal envelopment on each of them before assuming an earthly body. ${ }^{120}$ Thirdly, the Milky Way crosses the Zodiac circle at two tropical signs: Cancer and Capricorn,

\footnotetext{
114 Pallas, On the Mysteries of Mithras.

${ }^{115}$ Numen. De immortalitate animae fr. B 44 Leemans.

${ }_{116}^{116}$ LEEMANS (n. 107) 150.

${ }^{117}$ Eubulus, On Mithras in: Porph. De antr. nymph. 6.

${ }_{118}$ Numen. fr. $60^{*}$ des Places in Porph. De antr. nymph. 6.

${ }^{119}$ Numen. fr. B 44 Leemans in Porph. De antr. nymph. 28.

${ }^{120}$ Numen. fr. B 47 Leemans = Macrob. In Somn. 1. 11. 12.
} 
which are called portals of the Sun and are associated respectively with the Moon and Saturn. ${ }^{121}$ Through these two "mouths", allegedly mentioned by Plato in the "Orphic" myth of Er (Resp. 615d-e), the souls make their way down and up: they descend from the heavens through the gate of the moon at Cancer and, in turn, ascend to the heaven through the gate of the sun at Capricorn. ${ }^{122}$ The downward path leads the soul to its incarnation ( $\gamma \varepsilon \dot{\varepsilon} v \varepsilon \sigma 1 \zeta)$, whereas the upward path activates the reverse process of liberation from the body ( $\dot{\alpha} \pi \mathrm{o} \gamma \varepsilon \dot{\varepsilon} \varepsilon \sigma 1 \varsigma) .{ }^{123}$

Numenius was the first to assign the gaps in the heaven, known from Plato's Republic, to the sun gates at Cancer and Capricorn, of which the former one corresponds to birth (genesis), and the latter one to death of the body (apogenesis). Mithras has been mentioned by name in the context (Pallas in Porph. De antr. nymph. 24). The text, however - in the opinion of Attilio Mastrocinque ${ }^{124}$ - is not representative for Mithraism, because in Mithraism and the mysteries of Mithras alike Capricorn was as a sign of birth, moon, water, and the cosmic flood, and as such cannot be correlated with apogenesis. The Numenian passage, then, is unique and unparalleled by any Mithraic monuments except... the Modena relief.

\section{Tropic signs}

Let us take a closer look at the orientation of the god and the configuration of the tropic signs in the Modena relief. The figure of the young god is oriented not according to cardinal points (north, south, east, west), but according to tropic signs (Aries, Libra, Capricorn, Cancer). The god has Cancer on his right and Capricorn on his left, Aries above his head and Libra beneath his hoofs. Thus, the northern signs that descend from Cancer down to Capricorn (these are Leo, Virgo, Libra, Scorpio, Sagittarius) are placed under the lower eggshell, while the southern signs that ascend from Capricorn to Cancer back (these are Aquarius, Pisces, Aries, Taurus, Gemini) are situated above the god's solar-and-serpentine crown.

In the Numenian passage (quoted above), we read that the Zodiac signs are situated from Cancer to Capricorn in this order: Leo (the house of the Sun), Virgo (of Mercury), Libra (of Venus), Scorpio (of Mars), Sagittarius (of Jupiter), Capricorn (of Saturn), and then from Capricorn back to Cancer: Aquarius (assigned to Saturn), Pisces (to Jupiter), Aries (to Mars), Taurus (to Venus), Gemini (to Mercury), Cancer (to the Moon). Of these Numenius and Cronius say that the gate through which souls descend is Cancer, but that they ascend through Capricorn. Cancer, the summer tropic, is northerly, as influenced by Boreas, while Capricorn, the winter tropic, is southerly. We read, furthermore, that Mithras, the lord of genesis who takes a seat at the equinoxes, has the northern signs on his right, and the southern ones on his left,

${ }^{121}$ Numen. fr. B 47 Leemans = Macrob. In Somn. 1.11.12-1. 12. 1; Numen. fr. B 43 Leemans = Porph. De antr. nymph. 21; Numen. fr. B 44 Leemans = Porph. De antr. nymph. 28.

${ }_{122}$ Numen. fr. B 43 Leemans = Porph. De antr. nymph. 22.

${ }^{123}$ Porph. De antr. nymph. 23; Pherec. D-K 7 B 6 in: Porph. De antr. nymph. 31.

${ }^{124}$ MASTROCINQUE: The Mysteries (n. 30) 247-248. 
and bears the sword of Ares, and rides the bull of Aphrodite. By saying that Mithras has the northern and southern signs on his right and left, respectively, Numenius probably meant Cancer that is the northerly, and Capricorn that is southerly. As concerns the sword and the bull, Numenius or Pallas supposedly referred to Aries, which is the house of Mars, and to Libra rather than to Taurus (which is the author's mistake $^{125}$ ), the Zodiac sign assigned to Venus.

In sum, we have the complete description of the Modena youth who has Cancer on his right and Capricorn on his left, Libra under his feet and Aries under his head. The orientation of the silhouette according to four tropic signs seems to follow the Numenian passage. Which does not mean that the Modena relief represented Mithras or it has anything to do with Mithraism.

Numenius' Mithras has his seat at the equinoxes and this is why he supervises humans' births and deaths, and the entire cycle of reincarnation. The god Mithras is

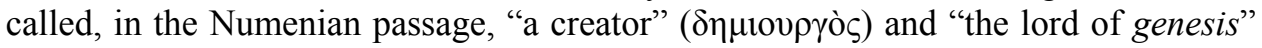
( $\gamma \varepsilon v \varepsilon ́ \sigma \varepsilon \omega \varsigma \delta \varepsilon \sigma \pi \delta ́ \tau \eta \varsigma)$. Accordingly, Eubulus, the ancient expert in Mithraism, was convinced that the mysteries of Mithras implied the belief in transmigration of the human souls into animal bodies, ${ }^{126}$ and similarly Pallas saw an allegory of metempsychosis in the Mithraic titles of "lions", "hyenas", "ravens", "eagles" and "hawks"; 127 of these only "lions" refer to a Mithraistic grade of Leo. ${ }^{128}$ Besides, the latter expert says that these titles, according to the opinio communis, were associated with the circuit of the Zodiac. ${ }^{129}$ Eubulus, Pallas, Numenius et consortes notoriously speak of reincarnation in the mysteries of Mithras.

It is highly questionable, however, whether Mithras was worshipped as a creator $\operatorname{god}^{130}$ and the patron of reincarnation, and then whether Mithraists believed in reincarnation. ${ }^{131}$ There is no evidence for this, except the Numenian passage and Porphyry's De abstinentia 4 . 16. The question is whether the Middle-Platonists, who evidently were not initiated into the mysteries of Mithras, were well acquainted with the Mithraic theology, or not. On the other hand, the Rhapsodic Phanes matched the characteristics given to Mithras by Numenius. Phanes was the one who created all things "in his murky cavern". ${ }^{132} \mathrm{He}$ is invoked in the Orphic Hymn 6. 3 as "genesis of

${ }^{125}$ BECK, R.: The Seat of Mithras at the Equinoxes: Porphyry, De antro nympharum 24. Journal of Mithraic Studies 1.1 (1976) 97-98; UlANSEY (n. 39) 60.

${ }^{126}$ Eubulus, On Mithras in Porph. Abst. 4. 16. 2: "For it is the belief of them all that metempsychosis is of the first importance, and this, apparently, they reveal in the mysteries of Mithras" (trans. Clark).

${ }^{127}$ Pallas, On Mithras in Porph. Abst. 4. 16. 3-4.

${ }^{128}$ Pallas (On the Mysteries of Mithras in Porph. Abst. 4. 16. 3) informs that: "The man who attains leontine rank puts on all kinds of animal forms" (trans. Clark). The ritual is otherwise unknown.

${ }^{129}$ Pallas, On Mithras in Porph. Abst. 4. 16. 4: "Pallas, giving the reason for this in his books on Mithras, says the general opinion is that it has to do with the $<$ lacuna $>$ of the circuit of Zodiac, but that the true and correct explanation is an allegory of human souls, which, they say, put on all kinds of bodies" (trans. Clark).

${ }^{130}$ TURCAN (n. 110) 77-88.

131 Alvar, J.: Romanizing the Oriental Gods: Myth, Salvation and Ethics in the Cults of Cybele, Isis and Mithras. Trans. R. Gordon. Leiden 2008, 128-129.

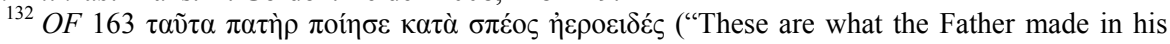
murky cavern", trans. Runia and Share). 
blessed gods and human beings" ( $\gamma \varepsilon \dot{v} \varepsilon \sigma v v \mu \alpha \kappa \alpha ́ \rho \omega v \theta v \eta \tau \tilde{\omega} v \tau$ ' $\dot{\alpha} v \theta \rho \omega ́ \pi \omega v) .{ }^{133}$ The Orphic poems, including the Orphic Rhapsodies, propagated the doctrine of reincarnation, ${ }^{134}$ which was a hallmark of ancient Orphism.

In the Numenian passage, the allegorization of the tropic signs is aimed at the doctrine of reincarnation. Numenius and his pupil Cronius say that the human soul goes in nascence through the tropic of Cancer, which is called the Moon gate because Cancer is assigned to the Moon, and goes out through the tropic of Capricorn, which is identified with the Sun gate, although Capricorn is assigned to Saturn. Furthermore, they say that Boreas, the cold northern wind, is responsible for incarnation $(\gamma \varepsilon \dot{\varepsilon} \varepsilon \sigma 1 \varsigma)$, and the hot southern wind Notus ${ }^{135}$ has control over the inverse process of dying ( $\dot{\alpha} \pi \mathrm{o}^{-}$ $\gamma \varepsilon$ ve $\sigma ı)$. In the Modena relief, we can find both of these winds pictured as winged male heads: Boreas holds a place at the bottom left corner (cf. fig. 9), and Notus at the top right (cf. fig. 7). ${ }^{136}$

\section{CONCLUSION}

Trying to answer the question what deity is represented by the Modena relief, I have analyzed eight features of the Modena god. These were the following: (1) the enormous, inverted egg, inside which the god stands; (2) the company of four Winds; (3) the golden wings grown out of the god's shoulders; (4) four mystic animals jointed with the god's body: he-goat, lion, ram, and a huge snake; (5) the attributes that the god bears: the solar rays and the lunar crescent; (6) a long scepter in the hand of the god; (7) the Zodiac band encircling the god in the egg; (8) the orientation of the god according to tropic signs: Aries, Cancer, Libra, Capricorn.

Of these, five motifs (nos $1,3,4,5,7)$ fit in the "oecumenical" theology of Hieronymus and Hellanicus as well as the "standard" Orphic theology verbalized in the Orphic Rhapsodies, and then correspond to the description of the Orphic god Phanes. In the Orphic Rhapsodies Phanes played a crucial part as the first god and the creator of the universe, whereas in the alternative theology of Hieronymus and Hellanicus the role of Phanes was minimized to the position of the third god, called Phanes, Zeus, Pan, and even Horomazes. Nevertheless, three other motifs (nos 2, 6, 8) cannot be related to the theology of Hieronymus and Hellanicus, but can be explicable on the ground of the Orphic Rhapsodies.

${ }^{133}$ OF 143. 3 = Hymn. Orph. 6. 3.

${ }^{134}$ OF 338: "The same (sc. people) inhabit their house as fathers and sons, as respected wives and cherished daughters, become each others in alternating generations $<\ldots>$ This is why the soul changes abodes, in cycles of time, goes from human bodies into animal ones, to become either a horse, or a $<--->$ either a ram, or bird of prey, a dreadful look, either a canine species to bark with deep voice, or one of cold serpents that crawl on the earth" (trans. Osek).

${ }^{135}$ The names of the winds are given in Porph. De antr. nymph. 25.

${ }^{136}$ At this point, I almost disagree with Maarten J. Vermaseren who identified the Winds as follows: "In the corners the heads of the winds, two young and beardless, two shaggy and bearded: Zephyrus (top right); Notus (top left); Boreas (bottom left); Eurus (bottom right).” See CIMRM (n. 4) 254. 
The most striking is the final motif (no. 8). The orientation of the Modena god according to tropic signs is unparalleled by any Mithraic monuments and cannot be linked to Mithraism, but it harmonizes with the Numenian passage, quoted by Porphyry, on Mithras' seat at the equinoxes and the configuration of Phanes' tablets referred to in Nonnus' Dionysiaca after the Orphic Rhapsodies. We are told that these tablets were engraved by the primeval Phanes, and that each of them is marked with a Zodiacal emblem. The world history starts with the tablet of Aries (which is above the head of the Modena god). The rise of the first human generation occurred in the sign of Gemini (which is lighted with the torch the Modena god holds in his right hand). The cosmic flood happened in the sign of Cancer (which is on the right of the Modena god), and the new race of people, moulded out of earth and water, arised in the sign of Leo (next to Leo there are visible the obliterated letters, which might be the original dedicatory inscription). The clay-made people were saved from despair by Dionysus' invention of wine in the sign of Libra (which is under the feet of the Modena god). Finally, the world history ends with the twelfth tablet marked with Pisces - at this sign is aimed the scepter the Modena god holds in his left hand. Numenius claims that the orientation of the god Mithras according to the tropic signs makes him the lord of the generation, because the human souls enter the world through the moon gate at Cancer, and leave the world through the sun gate at Capricorn. Mithras, so far as we know, did not patronize the cycle of reincarnation, as did the Orphic Phanes whom the Orphic Rhapsodies glorified as the lord of genesis.

Returning to the question that was asked at the beginning of this text: to what deity the Modena relief was dedicated, I would answer that there is no reason to consider the monument as "syncretistic" or "Mithraic". It is true that the relief was reused, probably twice, by the Mithraists, but what we can see on it (cf. figs 8 and 9) are not any dedicatory inscriptions but rather ancient graffiti. It is clear that the relief represents the lord of genesis, or the patron of reincarnation, but certainly not Mithras. The literary sources we analyzed above lead to the conclusion that the god shown in the Modena relief is compatible with the Orphic Phanes, who was described in details in the Orphic Rhapsodies, and that the Modena relief represents the coherent iconographic program that was easy to decipher for people well acquainted with the Orphic poems. Therefore, the Modena relief may be regarded not only as "the ultimate in mystery iconography", 137 but also as a unique representation of Phanes, the cosmic deity par excellence, which has come down to us from Graeco-Roman antiquity.

Ewa Osek

The Institute of Classical and Oriental Studies

The John Paul II Catholic University of Lublin

Poland

ewaosek@wp.pl

${ }^{137}$ Godwyn, J.: Mystery Religions in the Ancient World. San Francisco 1981, 170-171. 
